\title{
Regulation of Neurotrophin Receptor Expression during Embryonic and Postnatal Development
}

\author{
Enrique Escandón, ${ }^{1}$ Dan Soppet, ${ }^{3}$ Arnon Rosenthal, ${ }^{1}$ José-Luis Mendoza-Ramírez, ${ }^{1,4}$ Éva Szönyi, ${ }^{1}$ Louis E. \\ Burton, ${ }^{2}$ Christopher E. Henderson, ${ }^{5}$ Luis F. Parada, ${ }^{3}$ and Karoly Nikolics ${ }^{1}$ \\ 'Departments of Neuroscience and 2Process Sciences, Genentech, Inc., South San Francisco, California 94080-4990, \\ ${ }_{3}^{3}$ Molecular Embryology Section, ABL-Basic Research Program, NCl-Frederick Cancer Research and Development Center, \\ Frederick, Maryland 21702-1201, ${ }^{4}$ Instituto de Fisiología Celular y Departamento de Fisiología, Facultad de Medicina, \\ UNAM, Mexico 04510, and ${ }^{5}$ Biochimie CNRS INSERM, 34033 Montpellier Cedex, France
}

\begin{abstract}
Members of the NGF family of proteins act as neurotrophic agents for defined populations of peripheral and central neurons during embryonic and postnatal development. We have studied the presence of receptors for brain-derived neurotrophic factor (BDNF) and neurotrophin-3 and $-4 / 5$ (NT-3, NT$4 / 5$ ) by cross-linking radioiodinated neurotrophins to specific cell surface receptors. We have identified neurotrophin receptors representing full-length TrkB and TrkC and their truncated forms (lacking a functional cytoplasmic kinase domain) in neuronal as well as in non-neuronal tissues. During chicken embryonic and early postnatal brain development, expression of full-length TrkB and TrkC proteins preceded the onset of the truncated forms of these receptors. A similar pattern was also observed in mouse embryonic and early postnatal brain. The relative levels of neurotrophin receptors in the basal forebrain and in the hippocampus did not change significantly with age in mice. High levels of receptors for the three neurotrophins were detected in the nigrostriatal system. Full-length TrkB and TrkC receptors were found in chicken and rat embryonic ventral spinal cord, as well as on purified motoneurons. Again, truncated TrkB appeared significantly later than the full-length form on spinal motoneurons. In chicken embryonic retina and optic tectum we detected full-length TrkB and TrkC; however, the optic tectum also expressed large amounts of the truncated form of TrkB. TrkC but not TrkB was detected in chicken embryonic skeletal muscle, suggesting that NT-3 may have a novel function in this tissue. The presence of neurotrophin receptors in a wide variety of embryonic and postnatal tissues underlines the significant role of BDNF, NT-3, and NT-4/5 in embryonic and postnatal development. The regulation of the ratio of full-length versus truncated neurotrophin receptors may play an important role in the development, maturation, and maintenance of various neuronal networks.
\end{abstract}

\footnotetext{
Received June 29, 1993; revised Sept. 8, 1993; accepted Sept. 21, 1993

We thank Charles Schmelzer and Evelyn Martin for purifying recombinant neurotrophins and Kerri Andow and Wayne Anstine for help with the figures. L.F.P.'s and D.S.'s research was sponsored by the National Cancer Institute DHHS, under contract NOI-CO-74101 with ABL. The contents of this publication do not necessarily reflect the views and policies of the DHHS, nor does mention of trade names or commercial products imply endorsement by the U.S. Government.

Correspondence should be addressed to Karoly Nikolics. Ph.D. Dcpartment of Neuroscience, Genentech, Inc. MS 72, 460 Point San Bruno Boulevard, South San Francisco, CA 94080-4990.

Copyright 01994 Society for Ncuroscience $0270-6474 / 94 / 142054-15 \$ 05.00 / 0$
}

[Key words: brain-derived neurotrophic factor, neurotrophin-3, neurotrophin-4/5, neurotrophins, neurotrophin receptors, TrkB, TrkC, affinity cross-linking, development]

Neurotrophic factors regulate the proliferation, differentiation, process outgrowth, and survival of specific neuronal populations, and thus play a vital role in vertebrate neuronal development. Members of the "neurotrophin family"-NGF, brainderived neurotrophic factor (BDNF), and neurotrophin-3 and $-4 / 5$ (NT-3, NT -4/5) - support the embryonic survival and regulate the transmitter phenotype of responsive neuronal populations. Among these are dorsal root ganglionic (DRG) sensory and sympathetic neurons in the PNS; and basal forebrain cholinergic, nigral dopaminergic, and spinal cord motor neurons and retinal ganglionic neurons in the CNS (Hefti et al., 1989; Chao, 1992: Davies et al., 1993; Persson and Ibañez, 1993). Identification of functional receptors of neurotrophins in different tissues may reveal potential unrecognized biological activities of these molecules. Studies of neurotrophin receptors in cmbryonic, adult, and aging tissues will lead to a better understanding of the roles of these agents in regulating the development and maintenance of neuronal and possibly non-neuronal systems.

Functional receptors for neurotrophins can be identified and characterized by chemical cross-linking, also known as affinity labeling, a method that can provide size information on the receptor-ligand complex, as well as an estimate of binding affinity (Escandón et al., 1993). All neurotrophins bind to the "low-aflinity," or "fast," NGF receptor, also referred to as p75.NGr (Johnson et al., 1986; Radeke et al., 1987; RodriguezTébar et al., 1990, 1992). The expression of $p 75^{\text {NGFR }}$ is very widespread during embryonic development (Yan and Johnson, 1987; Escandón and Chao, 1989, 1990). In addition, neurotrophins bind to and stimulate tyrosine phosphorylation of members of the Trk protein family. The product of the trk protooncogene is a receptor tyrosine kinase that becomes activated upon NGF binding (Kaplan et al., 1991 a,b; Klein et al., 1991a). BDNF is a ligand of the TrkB protein (Klein et al., $1991 \mathrm{~b}$; Soppet et al., 1991; Squinto et al., 1991), whereas NT-3 preferentially binds to and stimulates the phosphorylation of the TrkC protein (at 0.01-0.1 nm concentrations) but is also able to bind to and phosphorylate the TrkB and Trk proteins at higher concentralions (0.2-1 nM) of the factor (Lamballe et al., 1991; Soppet et al., 1991; Tsoulfas et a1., 1993). NT-4/5 stimulates phosphorylation of TrkB and, to a lesser degree, Trk (Berkemeier et al., 1991; Yp et al., 1992). However, detailed binding studies with 
NT-4/5 have not been reported yet. Several splice variants of the $t r k \mathrm{~B}$ and $t r k \mathrm{C}$ genes have been described, some of which encode proteins that have an intact extracellular domain but lack the cytosolic catalytic tyrosine kinase domain (Klein et al., 1990a; Middlemas et al., 1991; Tsoulfas et al., 1993). Some of these transcripts encode unique C-terminal sequences.

In the CNS, the levels of p140 protork (further referred to as Trk) are extremely low (Martin-Zanca et al., 1990) and are mainly localized to basal forebrain cholinergic nuclei that are dependent on NGF (Holtzman et al., 1992). Transcripts for trkB and trkC are abundant during development and in adult animals (Klein et al., 1990b; Lamballe et al., 1991; Tessarollo et al., 1993; Tsoulfas et al., 1993). BDNF and NT-4/5 are the primary ligands of TrkB and NT-3 of TrkC. We therefore focused our analysis using receptor cross-linking on these receptors. Due to the complexity of the multiple $t r k \mathrm{~B}$ and $t r k \mathrm{C}$ transcripts, analysis of trk family mRNA expression in different tissues alone does not allow conclusions regarding functional receptors for the three neurotrophins. Here we report the identification by affinity labeling of functional neurotrophin receptors in embryonic and postnatal tissues as a more informative measure than previous mRNA expression studies. The results provide evidence for an active role of the neurotrophins in the formation and maturation of the nervous system and reveal non-neuronal tissues as possible novel targets for nonconventional neurotrophin effects. Based on our analysis described in this report, neurotrophin receptors appear to be developmentally regulated in a tissue-specific manner.

\section{Materials and Methods}

Neurotrophins and their radiolabeling. Recombinant NGF, BDNF, NT3 , and NT-4/5 were prepared essentially as described by Schmelzer et al. (1992), Rosenthal et al. (1990, 1991), and Berkemeier et al. (1992), respectively, with minor improvements. $\mathrm{N}$-terminal sequence analysis indicated that fully intact, properly processed mature forms of each neurotrophin were present in the preparations with less than $5 \%$ internally processed sequences. The purity of the protein preparations was confirmed by SDS-PAGE, which indicated a $>95 \%$ degree of purity as judged by Coomassie blue staining of the gels. Mass spectrometric analysis of the preparations was in agreement with $>95 \%$ of the full-length, unprocessed form of each neurotrophin. The proteins were quantitated for cross-linking and binding studies by amino acid analysis employing norleucine as an internal standard.

Neurotrophins were iodinated using the Enzymobead reagent (BioRad) as described (Escandón et al., 1993). Briefly, the beads were rehydrated in $2 \mathrm{ml}$ of distilled water overnight at $4^{\circ} \mathrm{C}$, centrifuged, and resuspended in $180 \mu \mathrm{l}$ of distilled water. Fifty microliters of the Enzymobead suspension were added to the iodination reaction described by the manufacturer. The mixture was incubated for $2 \mathrm{hr}$ at room temperature. An additional $40 \mu \mathrm{l}$ of the resuspended beads was added and the reaction was incubated for another hour. Labeled neurotrophins were separated from free iodine using desalting columns (Pierce). Routinely $2 \mu \mathrm{g}$ aliquots of the neurotrophins were incubated in the presence of $1.5 \mathrm{mCi}$ of $\mathrm{Na}^{125} \mathrm{I}$ and preparations with specific activities ranging from 2000 to $3500 \mathrm{cpm} / \mathrm{fmol}$ were typically obtained. The ${ }^{125} \mathrm{I}$-derivatized factors were stored at $4^{\circ} \mathrm{C}$ and used within 2 weeks of preparation. All of the iodinated proteins had full biological activities in neuronal survival assays (Escandón et al., 1993).

Preparation of tissues. Balb/c mice were killed, and different brain regions were dissected in cold $\left(4^{\circ} \mathrm{C}\right)$ PBS containing $5 \mathrm{mg} / \mathrm{ml}$ glucose and sliced into smaller pieces. Cell suspensions from the different brain regions were prepared by gently passing the tissue through an 18 gauge needle until a homogeneous suspension was obtained. Large aggregates were removed from the cell preparation by allowing the samples to sediment for $1-2 \mathrm{~min}$ at $4^{\circ} \mathrm{C}$ and collecting the supernatant. No enzymatic treatment was used at any stage of these preparations in order to avoid possible modifications of cell surface receptor proteins. Brain, ventral spinal cord, retina, optic tectum, and various peripheral organs
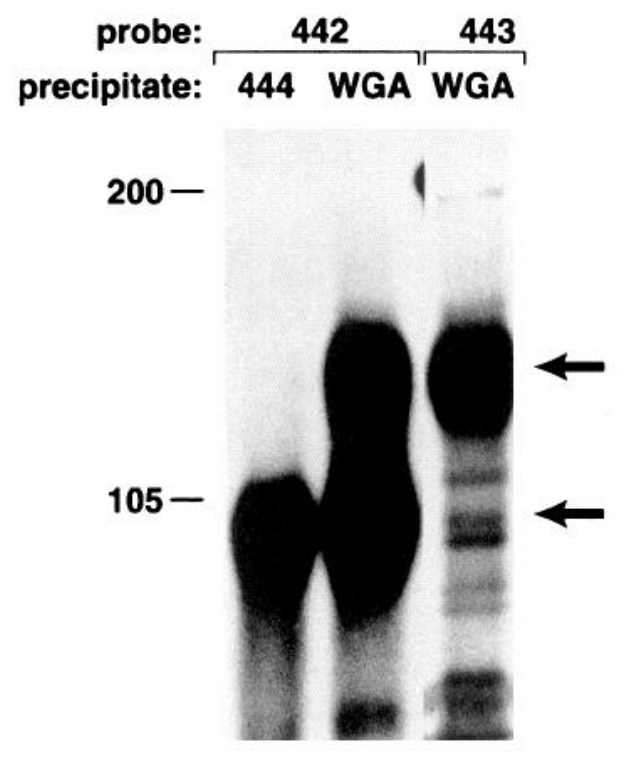

Figure 1. Western analysis of full-length and truncated TrkB receptors. NP-40 lysates of adult mouse cortex were precipitated with wheat germ agglutinin Sepharose $(W G A)$ or rabbit polyclonal antiserum 444 . The precipitates were resolved by $7.5 \%$ SDS-PAGE, transferred to nitrocellulose, and probed with TrkB-specific antiserum 442 or antiserum 443 , which recognizes the full-length form of the trk family of receptors. The reactive bands were visualized with HRP-conjugated anti-rabbit $\mathrm{IgG}$ and the ECL reagent. The lower arrow indicates the position of truncated TrkB receptor; the upper arrow indicates the position of fulllength TrkB receptor. Positions of prestained molecular size markers are indicated on the left in kilodaltons.

including heart, liver, kidney, gut, limbs, and, where indicated, skeletal muscle from chicken, mouse, and rat embryos and newborns were collected and treated similarly. Motoneurons were purified from chick [embryonic day 5 (E5)] or rat (E15) embryos as described (Bloch-Gallego et al., 1991; Camu and Henderson, 1992). Dissected non-neuronal tissues were mechanically triturated using a Brinkman homogenizer.

Preparation of antisera. Rabbit anti-peptide antisera were generated against keyhole limpet hemocyanin-conjugated peptides corresponding to mouse TrkB amino acids 45-60 (CTEPSPGIVAFPRLEP: peptide and antiserum 442) and 809-822 (NLAKASPVYLDILG: peptide and antiserum 443), and rat truncated TrkB tk-1 amino acids 454-465 (CGFVLFHKIPLDG: peptide and antiserum 444). Antiserum 443 recognizes Trk, TrkB, and TrkC expressed in NIH3T3 cells, whereas antiserum 442 is specific for full-length and truncated forms of TrkB (Soppet et al., 1991). Antiserum 444 recognize a truncated form of TrkB as shown by Western analysis of wheat germ agglutinin-extracted brain lysates (Fig. 1) and by Western analysis of cell lines expressing truncated TrkB (tk-1).

Affinity cross-linking procedures. For the receptor cross-linking experiments, the procedure of Escandon et al. (1993) was followed with some modifications. Cell triturations prepared from isolated tissues were incubated in PBS-glucose, $\mathrm{pH} 7.2$, with ${ }^{125}$ I-labeled neurotrophins (used in final concentrations of $0.5-1 \mathrm{nM}$, which corresponds to a maximally effective concentration of each neurotrophin). The samples were incubated at $4^{\circ} \mathrm{C}$ for $2 \mathrm{hr}$ with gentle agitation. The cross-linking agent 1-ethyl-3-(3-dimethyl-aminopropyl carbodiimide) $\mathrm{HCl}$ (EDAC; Pierce) was added to a final concentration of $6 \mathrm{~mm}$, and the mixture rotated for $20 \mathrm{~min}$ at room temperature. The reaction was quenched with cold PBS containing $50 \mathrm{~mm}$ lysine, centrifuged, and washed three times with PBS. The cell pellet was resuspended in PBS, $5 \mathrm{~mm} \mathrm{MgCl}_{2}$, and $1 \%$ Triton X-100 containing $1 \mathrm{~mm}$ phenylmethylsulfonyl fluoride, and treated with DNase I (5-10 $\mu \mathrm{g} / \mathrm{sample})$ for $15 \mathrm{~min}$ on ice. After centrifugation the supernatants were either immunoprecipitated or mixed with SDS sample buffer and subjected to electrophoresis on a $6 \%$ polyacrylamide SDS gel unless otherwise indicated. For immunoprecipitation the resuspended samples $(\sim 600 \mu \mathrm{l})$ were mixed with $5 \mu \mathrm{l}$ of each antiserum and incubated overnight at $4^{\circ} \mathrm{C}$, followed by a $2 \mathrm{hr}$ incubation in the presence of Protein A-Sepharose. The samples were washed three times 


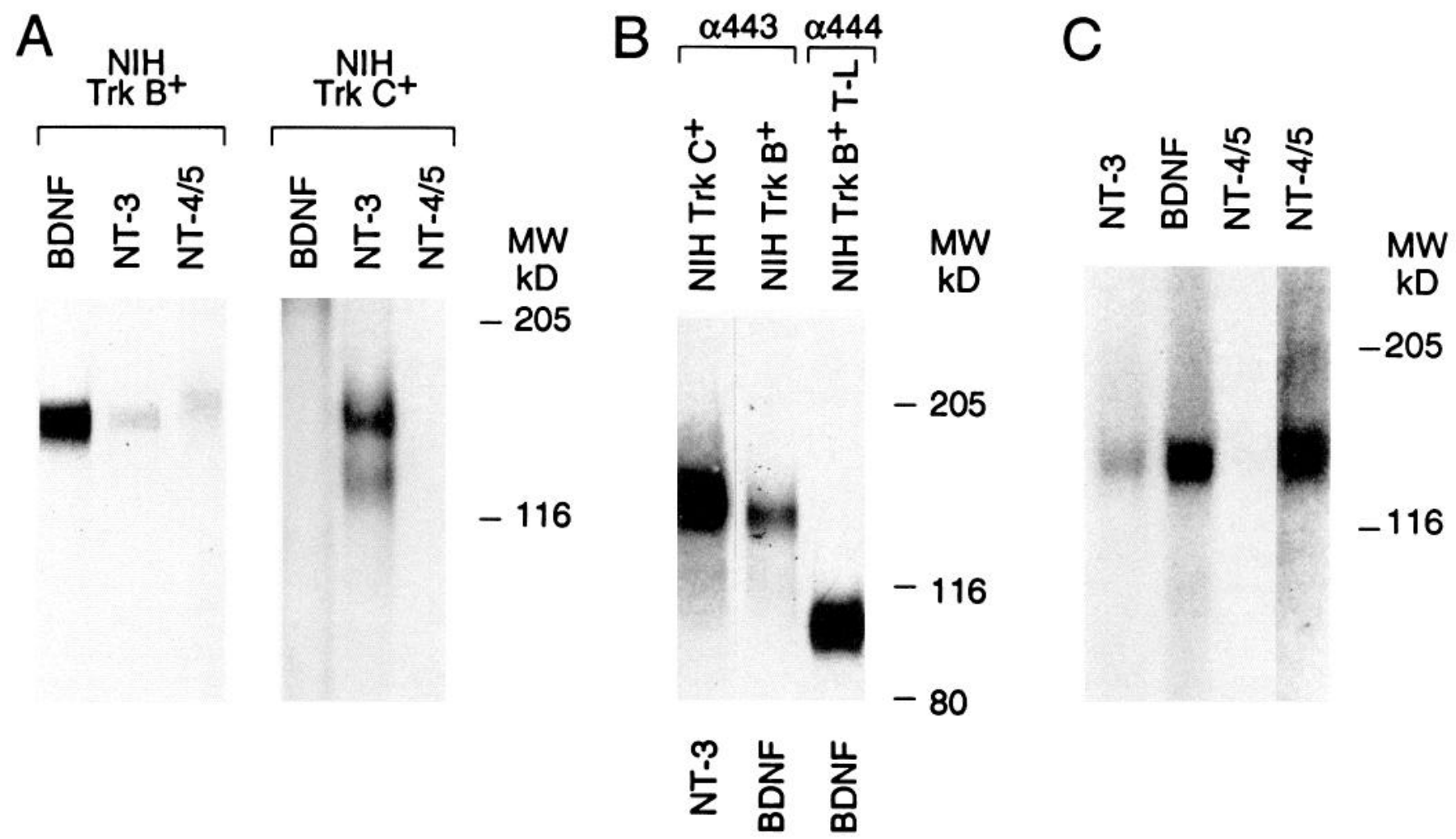

Figure 2. Specificity of neurotrophin affinity labeling and antibody reactivity with recombinant full-length TrkB and TrkC and truncated TrkB expressed in NIH3T3 cells $(A$ and $B)$ and with neuronal tissues $(C)$. Cell suspensions of NIH3T3 fibroblasts expressing recombinant full-length TrkB, TrkC, and truncated TrkB receptors $\left(N I H T r k B^{+} T-L\right)$ or membranes prepared from 6-month-old mouse cerebral cortex were incubated with $0.5-1 \mathrm{~nm}$ of the indicated labeled neurotrophins. Following EDAC cross-linking the samples were either resuspended in SDS sample buffer and subjected to electrophoresis on a $6 \%$ polyacrylamide/SDS gel $(A)$ or followed by immunoprecipitation with anti-443 or anti-444 antibodies as indicated. Samples in $C$ were all immunoprecipitated with anti-443 antibodies and treated as above. The fixed and dried gels were exposed with autoradiographic film. The second NT-4/5 lane in $C$ was exposed 10 times longer than all other lanes. Positions of molecular size markers are indicated in kilodaltons.

with the PBS, $1 \%$ Triton buffer and subjected to gel electrophoresis as described above. The fixed and dried gels were exposed with Kodak $\mathrm{X}-\mathrm{O}-\mathrm{Mat}$ film for different periods of time (as indicated in the figure captions) depending on the intensity of the label at $-70^{\circ} \mathrm{C}$ with an intensifier screen.

Binding assays. Crude membrane preparations from stable NIH3T3 fibroblast cell lines expressing full-length TrkB protein (100-200 mg of total protein/sample) were resuspended in Leibowitz's L-15 media (GIBCO) supplemented with $5 \mathrm{mg} / \mathrm{ml} \mathrm{BSA}$ and $0.1 \mathrm{mg} / \mathrm{ml}$ horse heart cyctochrome $\mathrm{C}$ (Sigma) and $20 \mathrm{~mm}$ HEPES, $\mathrm{pH}$ 7.2. Incubation of the binding mixture $(0.2 \mathrm{ml} /$ assay $)$ was carried out at $5^{\circ} \mathrm{C}$ with vigorous shaking overnight in $5 \mathrm{ml}$ polypropylene test tubes. Typically $50-200$ pM concentrations of iodinated BDNF or neurotrophin- $4 / 5$ were incubated with the membrane preparation together with increasing concentrations (1.56-6400 pM of BDNF or neurotrophin-3 or $-4 / 5$, or up to $100 \mathrm{nM}$ for NGF) of unlabeled competitors. Membrane-bound radioactivity was determined after the samples were transferred to Millipore filters in a filtration unit and washed three times with $3 \mathrm{ml}$ of ice-cold PBS containing $1 \mathrm{mg} / \mathrm{ml} \mathrm{BSA}$ and protamine sulfate (Sigma). The filters were counted in an Iso-data series 100 gamma counter with a counting efficiency of $78 \%$. Specific binding was calculated by subtracting the nonspecific binding from total binding. Nonspecific binding was measured by incubating the cell membranes with a 100 -fold excess of unlabeled homologous ligand.

\section{Results}

Cross-linking of neurotrophins to TrkB and TrkC receptors

Radioiodinated neurotrophins were cross-linked to specific receptors in various embryonic and postnatal tissues that were mechanically dispersed. NGF and the neurotrophins used in this study were produced by recombinant expression (Rosenthal et al., 1990, 1991; Schmelzer et al., 1991; Berkemeier et al., 1992). The purified factors were iodinated by a procedure using immobilized lactoperoxidase and glucose oxidase as described in detail elsewhere (Escandón et al., 1993). The radioiodinated neurotrophins were homogeneous as analyzed by SDS-PAGE and retained full biological activity in peripheral sensory neuron survival assays (Escandón et al., 1993). EDAC was used as the cross-linking agent, as we had earlier reported that it is very efficient in cross-linking iodinated BDNF and NT-3 to their respective receptors, TrkB and TrkC (Soppet et al., 1991; Escandón et al., 1993; Tsoulfas et al., 1993). In this study, in addition to BDNF and NT-3, the cross-linking of NT-4/5 was also tested to members of the Trk family.

The efficiency of analyzing the cross-linked reaction products could be significantly enhanced by immunoprecipitation with specific TrkB/C antibodies. We used two antibodies for this purpose, anti-443 and anti-444 (Fig. 1). Anti-443 is an antibody specific for the C-terminus of full-length TrkB; however, it also recognizes TrkA and TrkC. Anti-444 is an antibody specific for the truncated form of TrkB raised against a unique region of the C-terminus of this protein. The antibodies did not crossreact with $\mathrm{p} 75^{\mathrm{NGFR}}$ as tested by Western analysis and by immunoprecipitation of cross-linked BDNF-p $75^{\text {NGFR }}$ complexes (not shown; Escandón et al., 1993). Figure 1 shows Western analysis of full-length and truncated TrkB proteins; however, 


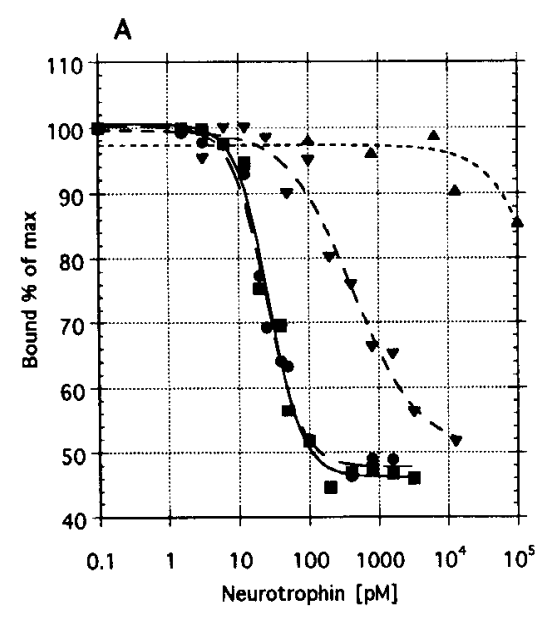

Figure 3. Self- and cross-competition analysis of BDNF $(A)$ and NT-4/5 $(B)$ binding to recombinant cells expressing p145 TrkB. Crude membrane preparations ( $150 \mu \mathrm{g}$ of total protein/tube) were incubated in the presence of 50-100 pM 125 I-labeled BDNF $(A)$ or ${ }^{125}$ I-labeled NT $-4 / 5(B)$ with increasing concentrations of homologous or heterologous unlabeled ligands. The symbols are as follows: $\boldsymbol{\square}$, BDNF; $\boldsymbol{\nabla}, \mathrm{NT}-4 / 5 ; \boldsymbol{\bullet}$, NT$3 ; \boldsymbol{\wedge}, \mathrm{NGF}$. The binding assay conditions are described in Materials and Methods. The competitor neurotrophin concentrations (picomolar) are indicated. both antibodies also efficiently precipitated cross-linked neurotrophin-receptor complexes (Fig. 2). As shown in Figure $2 A$, we were able to cross-link BDNF, NT-3, and NT-4/5 to TrkB; however, only NT-3 bound to TrkC. All neurotrophin-receptor complexes appeared as broad bands by SDS-PAGE analysis, probably reflecting the glycosylation of these receptor proteins. However, the cross-linked labeled products showed some differences. The $M_{r}$ of the receptor-ligand complex when BDNF and NT -3 were cross-linked to TrkB or TrkC was approximately $150-160 \mathrm{kDa}$, whereas in the case of NT-4/5 it was about $160-$ $170 \mathrm{kDa}$ (Fig. 2A). A possible reason for this is that the stoichiometry of the reaction between NT-4/5 versus BDNF and NT-3 to their receptors may differ. It is unclear whether neurotrophins are cross-linked to TrkB as monomers or as dimers. Depending on this, cross-linking increases the size of the receptor band by either 13.5 or $27 \mathrm{kDa}$. Cross-linking followed by immunoprecipitation with these two antibodies, respectively, to full-length and truncated forms of TrkB, and the full-length form of TrkC (Fig. $2 B$ ) proved to be a very useful method to analyze such products in tissues. The two antibodies are specific for either the full-length or the truncated forms of TrkB and no nonspecific cross-reactivity was seen. In most experiments described below, except where indicated otherwise, we used a mixture of these two antibodies in order to capture both forms of TrkB and the full-length form of TrkC.

\section{Specificity of neurotrophin binding and cross-linking to TrkB} and $T r k C$ receptors in vitro and in vivo

Using competition binding analysis we established that BDNF and NT-4/5 are equally efficient ligands to bind to TrkB (Fig. 3). Both agents bind to TrkB with high affinity ( $\mathrm{IC}_{50}$ values of about 15-25 pM) and were able to displace each other at the same concentrations. NT-3 was a significantly less efficient competitor with an $\mathrm{IC}_{50}$ value of about $300 \mathrm{pm}$ when either $\mathrm{BDNF}$ or NT-4/5 was used as the labeled ligands. The slope of the displacement curve with NT-3 significantly differed from those of BDNF and NT-4/5, suggesting that the molecular and kinetic details of the interaction between NT-3 and TrkB differ from those of BDNF and NT-4/5. NGF was inefficient in displacement of either BDNF or NT-4/5 from TrkB even at extremely high (10-100 mM) concentrations. These data indicate that both BDNF and NT-4/5 are specific high-affinity ligands of TrkB. The values obtained are similar to those reported for NGF-trk interactions (Vale and Shooter, 1985; Hempstead et al., 1991). In contrast to the displacement analysis, cross-linking of NT-
4/5 to TrkB, although specific and detectable, provided a significantly less intense signal as compared to BDNF (Fig. 2C). A 10-fold longer exposure time was required for NT-4/5 to achieve a signal intensity comparable to that obtained with BDNF. We attribute this to a lower efficiency of cross-linking of NT-4/5 to TrkB with EDAC; fewer amino acid side chains between NT-4/5 and TrkB may be available for the reaction. Whereas BDNF and $\mathrm{NI}-3$ have 11 and 10 lysines, respectively, NT-4/5 contains only three lysines that may be available for the cross-linking reaction (the number of Asp and Glu residues is approximately the same in all three NTs). In addition, crosslinking of NT-4/5 to chicken brain was not detectable under the same experimental conditions (not shown).

Using membranes from adult mouse cortex and E1 5 chicken brain, labeled BDNF, NT-3, and NT-4/5 were bound and crosslinked in the presence or absence of heterologous cold ligands followed by immunoprecipitation with a mixture of anti-443/ 444 (Fig. 4). The results indicated the presence of both fulllength TrkB and TrkC, as well as truncated TrkB in CNS tissues of both rodent and avian species. As we have previously shown, both BDNF and NT-3 were able to bind to truncated TrkB (Soppet et al., 1991; Escandón et al., 1993). Binding of NT-3 to truncated TrkB was completely displaced in the presence of $100 \times$ cold BDNF. These experiments also demonstrated that truncated TrkB appears to be the most abundant receptor form in the adult mouse cortex, whereas in E15 brain the full-length and truncated forms are present at similar levels (compare Fig. $4 A, B$ ). NT-4/5 also bound to full-length and truncated TrkB in mouse cortex. This was demonstrated by the complete displacement of labeled NT-4/5 binding when cold BDNF was the competitor, in agreement with the binding displacement analysis (Fig. 3). A $100 \times$ excess of unlabeled NT-3 partially competed with NT-4/5 binding.

The binding and cross-linking data can be summarized as follows. (1) BDNF and NT-4/5 bind and cross-link to full-length and truncated $\mathrm{TrkB}$ receptors, a signal that is not displaceable by cold NGF; however, some displacement is found with a large excess $(1-200 x)$ of NT-3. In tissues where intense labeling is seen with BDNF and relatively weak labeling with NT-3 in which the latter is displaceable with BDNF, we believe that predominantly TrkB receptors are present. (2) NT-3 binds and cross-links predominantly to TrkC receptors to which BDNF and NT-4/5 do not bind. NT-3 binds to TrkB but with lower affinity than BDNF and NT-4/5, its native ligands. Therefore, in tissues where only NT-3 but no BDNF or NT-4/5 cross- 


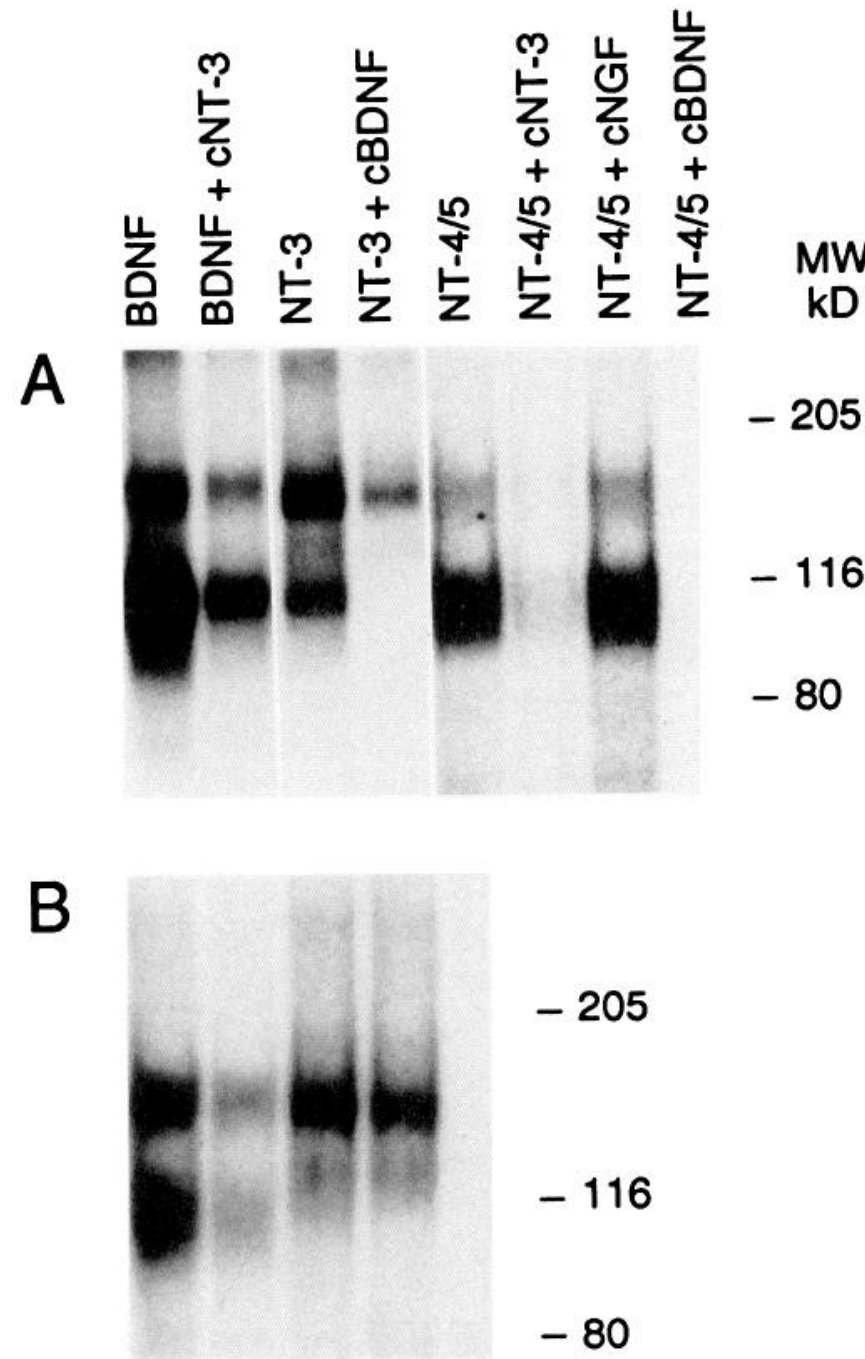

Figure 4. Effect of heterologous ligands on the affinity labeling of neurotrophin receptors in vivo: comparison between rodent and avian tissues. Equal amounts ( $5 \mathrm{mg}$ of total protein/sample) of crude membranes prepared from 6-month-old cerebral cortex $(A)$ or E15 chicken brain $(B)$ were incubated with $1 \mathrm{~nm}$ labeled neurotrophins in the presence or absence of a 150 -fold excess of heterologous ligand. Cold NGF was always used at a 1000-fold excess. Lane 1, BDNF; 2, BDNF + cold NT-3; 3, NT-3; 4, NT-3 + cold BDNF; 5 , NT-4/5; 6, NT-4/5 + cold NT-3; 7, NT- $4 / 5$ + cold NGF; 8, NT- $4 / 5+$ cold BDNF. After EDAC cross-linking the samples were immunoprecipitated with a mixture of anti-443/444 antibodies and analyzed by SDS-PAGE. The fixed and dried gels were exposed for $14 \mathrm{~d}$. Positions of molecular weight markers are indicated in kilodaltons.

linking was found, we believe that predominantly TrkC receptors are present. (3) In a few instances (with no immunoprecipitation with anti-443/444) we found NT-3 cross-linking to a truncated receptor species not displaced by BDNF that most likely represents a truncated TrkC species. (4) As discussed in detail below, in many if not most tissues TrkB and TrkC and even their full-length and truncated forms are coexpressed; however, in some tissues at certain developmental times "pure" examples with either TrkB or TrkC receptors only have been found.

\section{Neurotrophin receptors in the developing brain}

To better understand the role of the neurotrophins in neuronal differentiation, maturation, and survival, it is important to iden- tify the presence of their functional and specific receptors in vivo at different developmental and postnatal ages. Having established the cross-linking reaction conditions followed by immunoprecipitation with specific antibodies, and determined the ligand specificity of binding with recombinant receptors and brain tissue, we began to analyze functional receptors for the three neurotrophins in different tissues of different developmental and postnatal ages. Full-length and truncated forms of TrkB and TrkC are widely expressed in the adult CNS (Klein et al., 1990a,b; Escandón et al., 1993). Whereas full-length TrkB is the signal transducing receptor for BDNF and NT-4/5, it is still unclear what the role of truncated TrkB might be in vivo. We isolated chicken embryonic brains at different developmental times and subjected the tissues to affinity cross-linking using labeled BDNF and NT-3 followed by immunoprecipitation with anti- 443 or -444 antibodies (Fig. $5 A, B$ ). We detected the presence of receptor complexes as early as E6 for the full-length forms. By E11, binding of BDNF and NT-3 to TrkB and TrkC, respectively, produces intense signals. In contrast, under the same binding and cross-linking conditions, truncated TrkB was not detectable until later developmental times (approximately E13). However, as development progresses truncated TrkB becomes the predominant form, very similar to that observed in the adult mouse brain, as described above. These two isoforms are developmentally regulated during maturation of the CNS.

Analysis of neurotrophin receptors in mouse embryonic brain showed a similar pattern to that found in avian brain (Fig. $5 C$ ). At early stages of rodent brain development the most abundant receptor forms are the full-length receptors, although even at the earliest time analyzed (E12), truncated TrkB was already present. At later developmental stages, full-length TrkB and TrkC decreased and by adulthood truncated TrkB was the most abundant form. The similarities in the relative profiles of BDNF and NT-3 receptor levels in two distinct species suggest an important role for these neurotrophins in brain development and maturation. In order to detect the cross-linked receptor products of NT-4/5 during mouse brain morphogenesis it was necessary to expose the gels for significantly longer periods of time as compared to the strong signals of BDNF and NT-3 cross-linked to TrkB and TrkC. The receptor profile for NT $-4 / 5$ follows the pattern obtained with BDNF. NT-4/5 binding to full-length TrkB reaches a peak around $\mathrm{E} 17$ and gradually decreases to low levels in the adult when binding to the truncated form of TrkB represents the majority of the NT-4/5 cross-linked receptors. Binding of NT $-4 / 5$ was completely displaced by the addition of cold BDNF but not NGF to the incubation reaction.

To characterize further the nature of the neurotrophin receptors identified by our affinity cross-linking procedure, we also studied the developmental appearance of the full-length and truncated TrkB proteins in mouse brain by Western blot analysis antisera using 442 and 444 , specific against full-length TrkB and truncated TrkB, respectively. We prepared WGA-concentrated NP-40 extracts of whole brains from E13, E15, E17, E19, postnatal day 1 (P1), and adult mice. Equal protein loading of the extracts was resolved on a $7 \%$ SDS polyacrylamide gel and probed with antiserum 442 (Fig. 6, top). By E1 5 both truncated and full-length TrkB-encoded proteins are apparent at approximately equivalent levels. The levels of full-length TrkB increase between E15 and P1 and remain present in the adult. The levels of truncated receptor do not increase significantly until P1 and then rise dramatically in the adult. While not apparent from this exposure the truncated receptor in adult is severalfold higher 


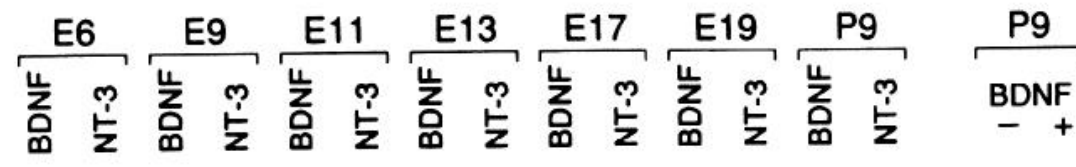

A
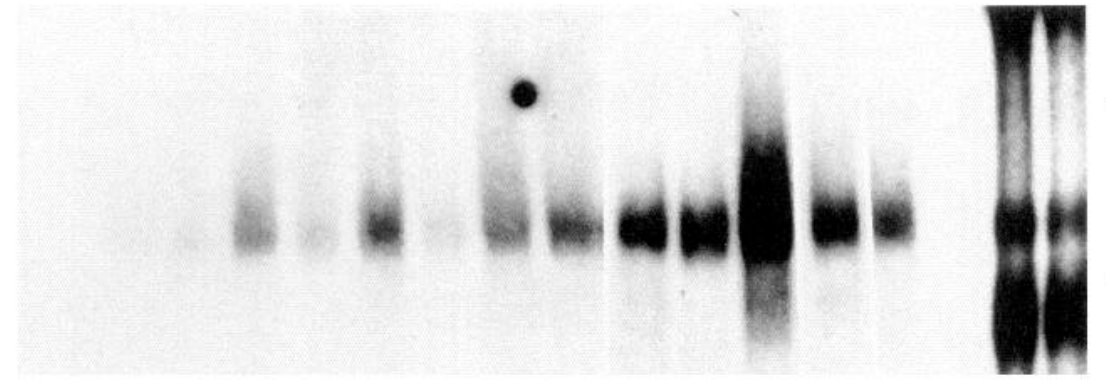

$-205$

$-116$
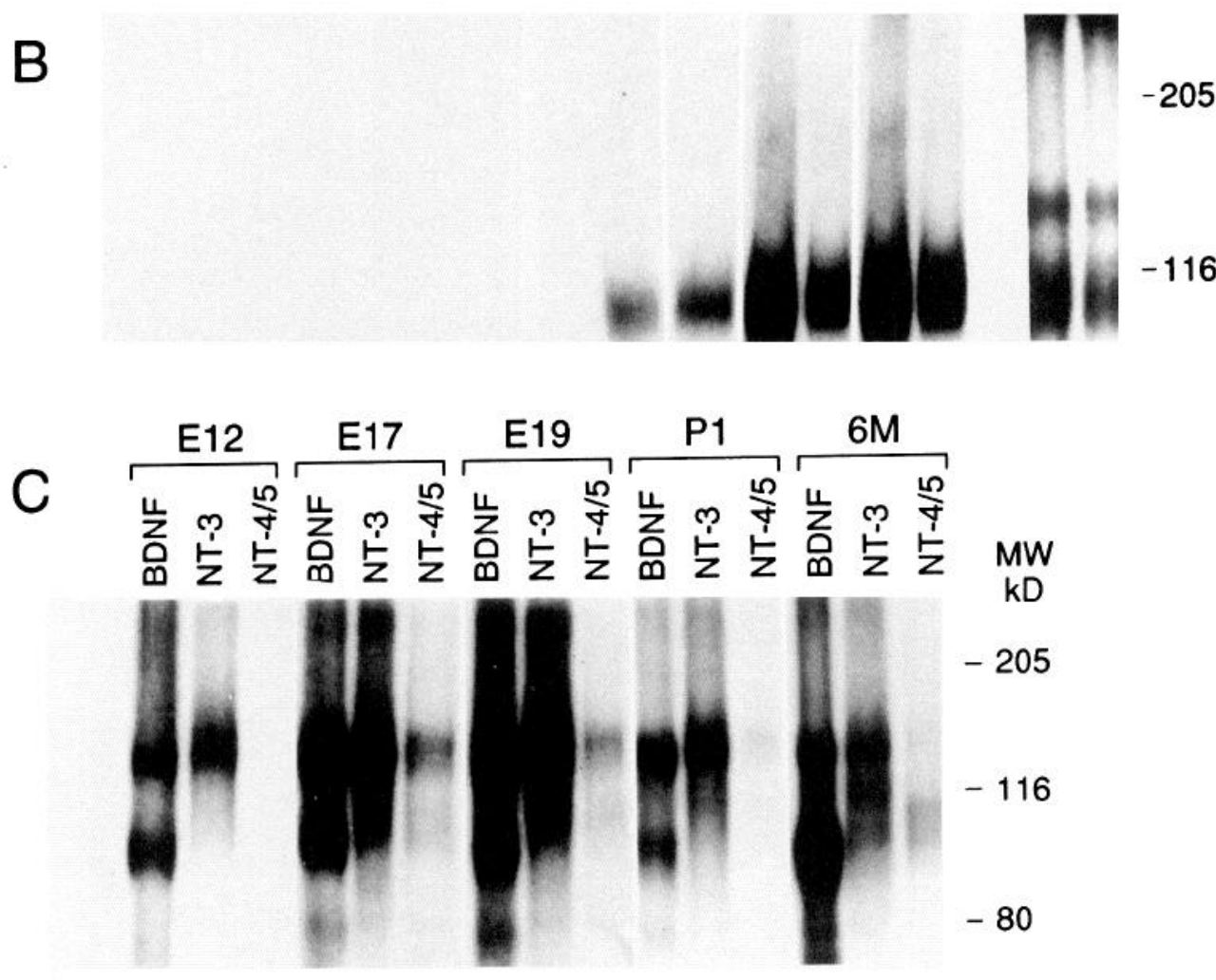

Figure 5. Binding of BDNF, NT-3, and NT-4/5 to full-length TrkB and TrkC and truncated TrkB receptors during brain morphogenesis. Crude membrane preparations derived from chicken $(A$ and $B$ ) and mouse brains $(C)$, isolated at different embryonic and postnatal stages, were incubated in the presence of $1 \mathrm{~nm}(A$ and $B)$ or $0.5 \mathrm{~nm}$ $(C)$ of the indicated labeled neurotrophins. After EDAC cross-linking the samples were immunoprecipitated with anti-443 $(A)$, anti-444 $(B)$, or a mixture of both $(C)$, and analyzed by SDSPAGE. The fixed and dried gels were exposed for $5 \mathrm{~d}(A$ and $B)$ or $14 \mathrm{~d}(C)$. The last two lanes in $A$ and $B$ were not immunoprecipitated in order to serve as a control for total binding. - and + indicate the absence or presence of a 1000 -fold excess of cold NGF. Positions of molecular size markers are indicated in kilodaltons. $6 M, 6$ months. than the full-length receptor. To verify the identity of the faster migrating form we stripped and reprobed the blot with antiserum 444 specific for the TrkB truncated form (Fig. 6, bottom). These results confirmed the identification of functional receptors for BDNF during development by affinity cross-linking.

\section{Neurotrophin receptors in the postnatal cortex}

The significant changes in full-length versus truncated forms of neurotrophin receptors seen in developing tissues prompted us to investigate receptor regulation at various postnatal times (Fig. 7). Cortical tissues from mice of 1,6 , and 18 months of age were used for cross-linking with BDNF and NT-3 in the presence and absence of heterologous ligands. The results demonstrate that after 1 month of age there were no significant changes in the levels and relative ratios of neurotrophin receptor forms. As already noted above, BDNF and NT-3 label overlapping receptors, that is, full-length and truncated forms of TrkB. When an excess $(100 \times)$ of unlabeled NT-3 is present during the labeling with BDNF, a partial displacement of binding to a fulllength receptor form (TrkB) can be observed and, conversely, labeling with NT-3 can be partially displaced with an excess of unlabeled BDNF. However, only BDNF can displace labeling of the truncated TrkB form, whereas NT-3 does not eliminate BDNF binding to full-length and truncated TrkB even at a $100 \times$ excess (compare Fig. $7 A, B$ ).

\section{Neurotrophin receptors in the basal forebrain and hippocampus}

Neurotrophins exert trophic effects on neurons of the basal forebrain that project to the hippocampus (Hefti et al., 1989; Knüsel et al., 1991, 1992). To begin to understand the differences in target responsiveness to different neurotrophins we analyzed their receptors in both neuronal tissues using BDNF, NT-3, and NT-4/5 (Fig. 8). We analyzed mouse basal forebrain and hip- 


\section{E13 E15 E17 E19 P1 adult}

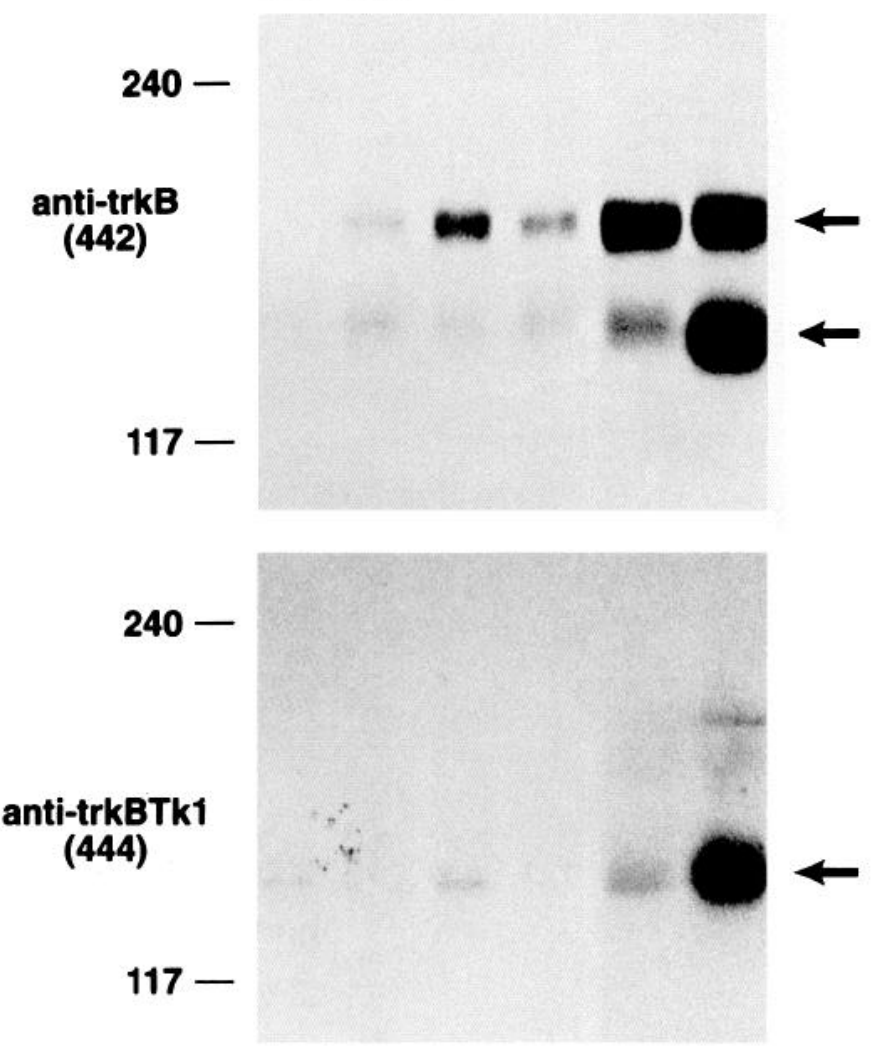

Figure 6. Developmental expression of TrkB receptors in the mouse by Western analysis. NP-40 lysates of cortex obtained from embryonic (E13, E15, E17, E19), neonatal (P1), or adult mice were precipitated with WGA-Sepharose; the precipitates were resolved by $7.5 \%$ SDSPAGE, transferred to nitrocellulose, and probed with TrkB-specific antiserum 442 (top), and then stripped and reprobed with truncated TrkBspecific antiserum 444 (bottom). The reactive bands were visualized with HRP-conjugated anti-rabbit IgG and the ECL reagent. Positions of molecular size markers are indicated in kilodaltons.

pocampal tissues obtained from animals of different ages in order to see if age-related changes could be detected. All three neurotrophins bound to receptors in both tissues; however, clearly detectable differences were found. Both basal forebrain and hippocampus are rich in full-length and truncated TrkB as demonstrated by the intense labeling with BDNF. A significant although lower degree of NT-3 labeling was also found in both tissues. In the basal forebrain (Fig. $8 B$ ) the amount of full-length receptors cross-linked with NT-3 was substantially lower in comparison to the extensive labeling with BDNF. These results are in direct agreement with the relative efficacies of the two neurotrophins in mediating survival effects of cholinergic neurons in the basal forebrain. In addition, NT-3 cross-linking showed unique differences in the relative binding to full-length TrkC versus truncated TrkB receptors in these tissues. NT-3 labeling of full-length TrkC was higher in the hippocampus where poor cross-linking to truncated TrkB was found. In contrast, in the basal forebrain full-length TrkC was diminished together with a substantial increase in the binding of NT-3 to truncated TrkB, which was very abundant in both tissues as judged by BDNF binding. Although additional studies are necessary to understand the biological implications of this differential regulation of neurotrophin receptor expression and bind-
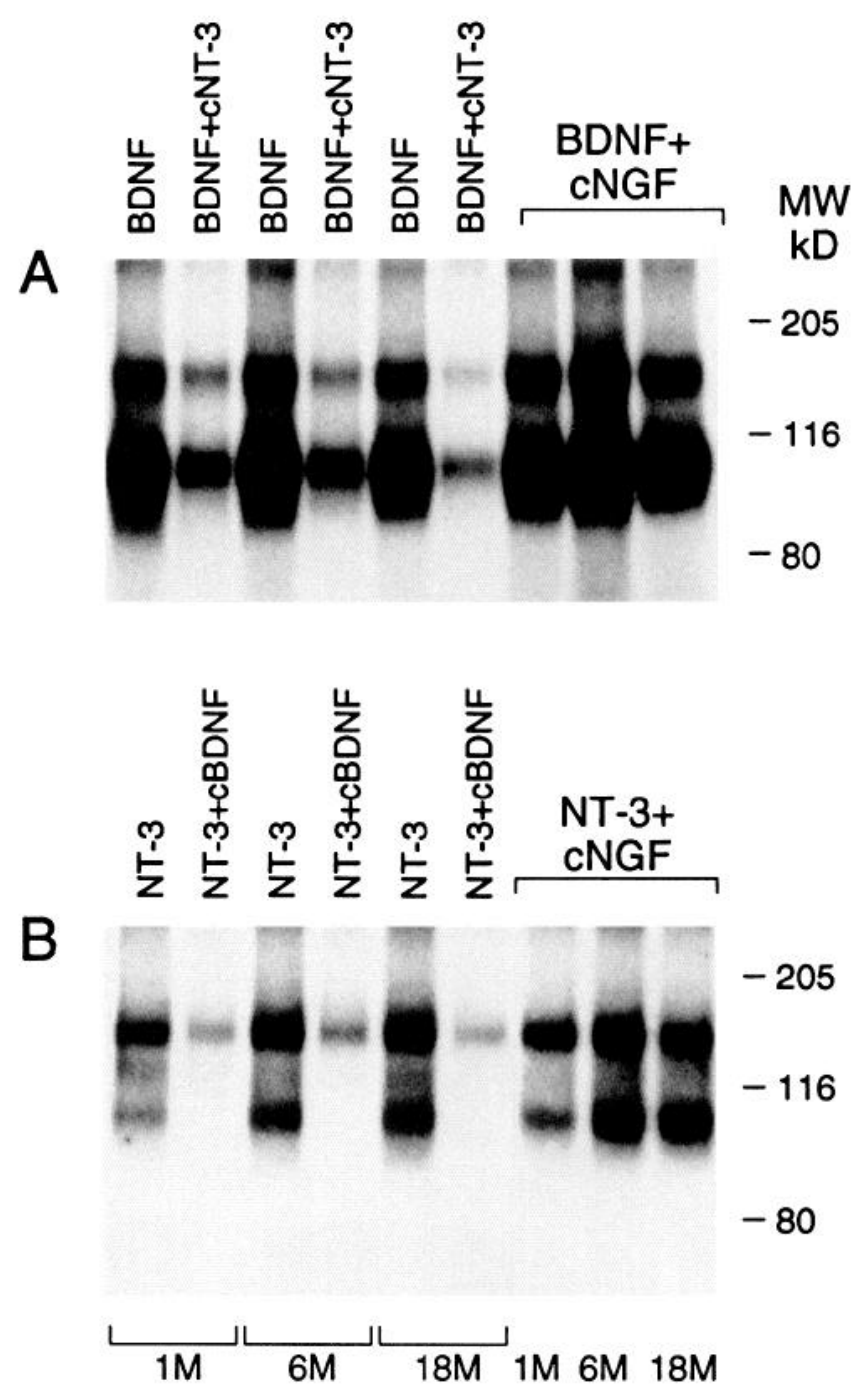

Figure 7. Expression profile and ligand specificity of neurotrophin receptors in the postnatal cerebral cortex. Crude membrane preparations from mouse cortex were dissected at progressive postnatal ages $(1,6$, and 18 months). Equal amounts of membranes $(5 \mathrm{mg}$ of total protein/ assay) were incubated with $1 \mathrm{~nm}$ labeled $\operatorname{BDNF}(A)$ or NT-3 $(B)$ in the presence or absence of unlabeled heterologous ligands. Following EDAC cross-linking and immunoprecipitation with a mixture of anti-443/444 antibodies, the samples were subjected to gel electrophoresis on a $6 \%$ SDS/polyacrylamide gel. Unlabeled BDNF and NT-3 were used at 150 fold excess, and NGF at 1000 -fold excess. The fixed and dried gel was exposed for $7 \mathrm{~d}$. The positions of the molecular size markers are indicated in kilodaltons.

ing activity, our results suggest a complex functional interaction between the different full-length and truncated Trk receptors with their respective ligands in vivo. NT- $4 / 5$ cross-linked receptor products showed a weak signal in both tissues similar to that observed and discussed above in whole embryonic brain. Only basal forebrain cross-linking of NT- $4 / 5$ is shown in a longer exposure time.

With the exception of a subtle decrease in full-length and truncated TrkB, we did not detect significant age-dependent alterations in the relative ratios or total amounts of the receptor complexes identified by affinity labeling with BDNF, NT-3, and NT-4/5. A similar analysis of whole-brain tissue in the presence of the heterologous cold ligand $(150 \times)$ provided similar results. 

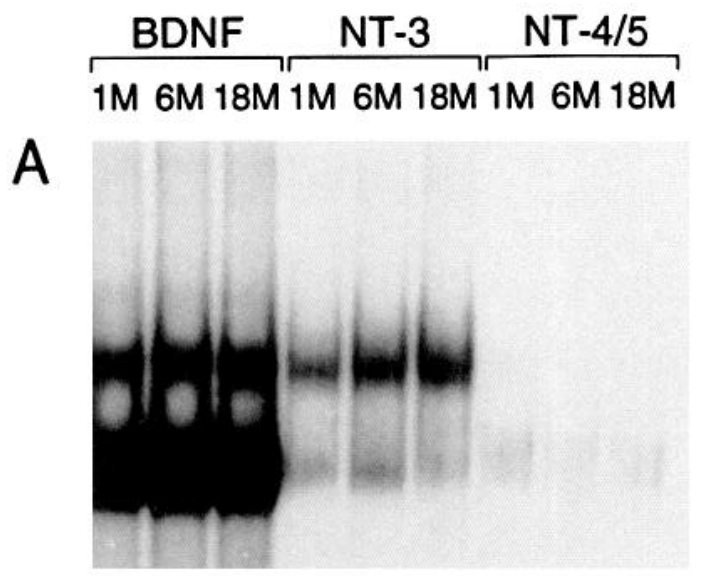

B

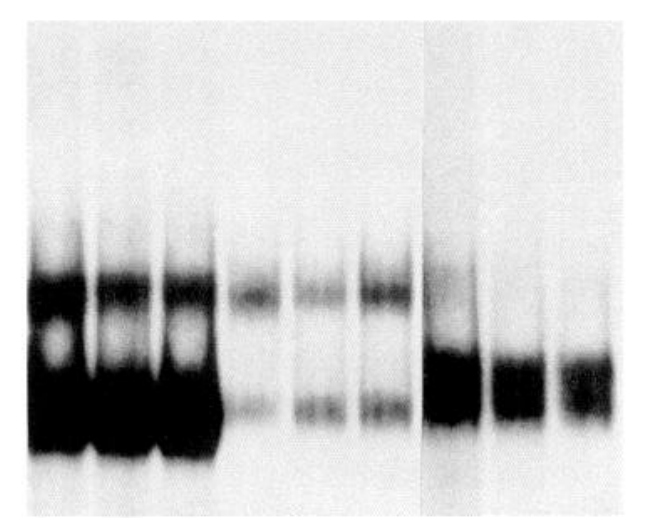

MW

$\mathrm{kD}$

$-205$

$-116$

$-80$

$-205$

$-116$

$-80$

Figure 8. Comparison of functional neurotrophin receptors identified in basal forebrain $(A)$ and hippocampus $(B)$ of young, adult, and aged mice. Dissected tissues were incubated in the presence of $1 \mathrm{~nm}$ labeled BDNF, NT-3, or NT-4/5. After EDAC cross-linking the samples were immunoprecipitated with a mixture of anti-443/444 antibodies and subjected to electrophoresis on a $6 \%$ polyacrylamide/SDS gel. The fixed and dried gels were exposed for $5 \mathrm{~d}$, with the exception of NT $-4 / 5$ crosslinking in $B$, which was exposed for $14 \mathrm{~d}$. The positions of the molecular size markers are indicated in kilodaltons.

The abundant NT- 3 binding to truncated TrkB was completely displaced by cold BDNF. On the other hand, cold NT-3 at 200x excess was unable to compete completely with the binding of labeled BDNF to full-length or truncated TrkB under these experimental conditions. In contrast, unlabeled NGF even at a $1000 \times$ excess failed to displace any noticeable level of either BDNF or NT-3 binding to trk receptors in vivo measured by affinity labeling.

\section{Substantia nigra and corpus striatum}

BDNF and NT- $4 / 5$ have been shown to act as trophic factors for dopaminergic neurons in the substantia nigra in vitro but not in vivo and both factors also protect this population of neurons from neurotoxic damage in vitro (Hyman et al., 1991; Knüsel et al., 1991, 1992; Hynes and Rosenthal, 1993). We therefore analyzed the presence of neurotrophin receptors in the substantia nigra, as well as the corpus striatum, the target area of the nigral neurons. Based on histochemical analysis the dissection procedure yielded tissue from newborn rat brain that was greater than $50 \%$ dopaminergic neurons (J.-L. Mendoza-Ramírez, unpublished observations). Interestingly, as shown in Figure 9, both tissues showed significant receptor levels when cross-linking with either BDNF, NT-3, or NT-4/5. The relative amounts

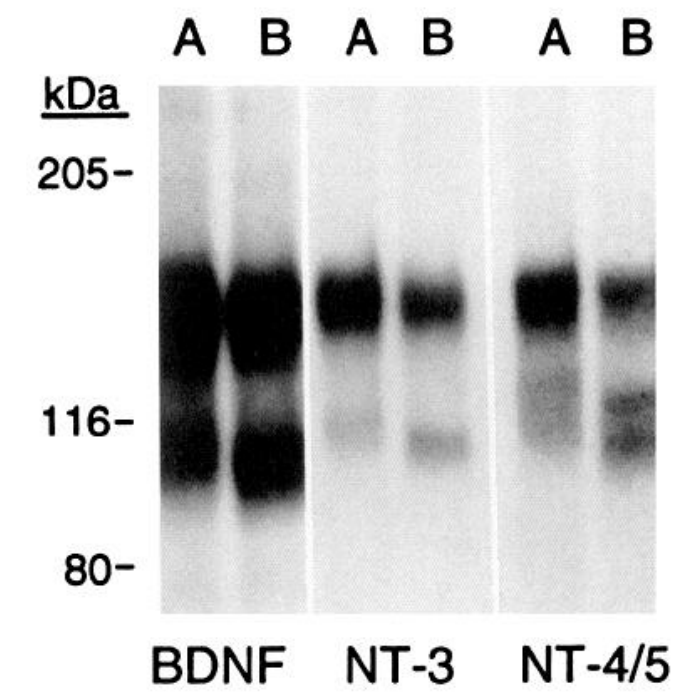

Figure 9. Receptors for BDNF, NT-3, and NT-4/5 in the neonatal nigrostriatal system. Corpus striatum $(A)$ and substantia nigra $(B)$ tissues were isolated from $\mathrm{Pl}$ rat brains and subjected to EDAC cross-linking $(0.75 \mathrm{mg}$ total protein/sample) in the presence of $1 \mathrm{~nm}$ radioiodinated neurotrophins, as indicated. Following affinity labeling, the samples were immunoprecipitated with a mixture of anti-443/444 antibodies and electrophoresed on a $6 \%$ SDS/polyacrylamide gel. The fixed and dried gel was exposed for $6 \mathrm{~d}$. The positions of the molecular size markers are indicated in kilodaltons.

of full-length and truncated receptors were not significantly different in the two tissues at this developmental stage. There was relatively more intense labeling with NT-4/5 as compared to that observed with other tissues.

\section{Neurotrophin receptors in developing spinal motoneurons}

Neurotrophin receptors in the spinal cord were analyzed with particular focus on the motoneuron population (Fig. 10). In embryonic chick ventral spinal cord, products corresponding to p75, full-length TrkB, and TrkC could be identified during the phase of naturally occurring motoneuron cell death (E5.5, E6.5, and E7.5). A dramatic increase in full-length TrkB and TrkC expression from E5.5 to E6.5 was observed while the relatively high levels of p75 remained constant. In purified motoneurons from E5 chick spinal cord (Bloch-Gallego et al., 1991) we were able to identify a very weak cross-linked product with NT-3 but not with BDNF or NT-4/5, suggesting that only low levels of full-length TrkC receptors were present at this early developmental age (Fig. 11). This is in agreement with the lack of survival effect of BDNF, NT-3, and NT-4/5 on motoneurons purified from E5 chick embryos (Arakawa et al., 1990; Henderson et al., 1993).

BDNF (Oppenheim et al., 1992; Sendtner et al., 1992; Yan et al., 1992) and more recently NT-3 and NT-4/5 (Henderson et al., 1993) have been reported to exert trophic effects on mammalian motoneurons in vivo and in vitro. In addition, mRNA for BDNF and NT-3 has been detected in rodent skeletal muscle at the time developing motoneurons undergo programmed cell death, strongly suggesting that neurotrophins play active roles in regulating motoneuron survival in vivo. We have identified functional receptors for BDNF, NT-3, and NT-4/5 in isolated rat ventral spinal cord tissues at E15, E17, and E20 (Fig. 12). Full-length forms of TrkB and TrkC are abundantly expressed during this developmental time, while truncated TrkB expres- 
A

Figure 10. Coexpression of p75 and trk receptors in developing avian ventral spinal cord. Viable cells $\left(1 \times 10^{6}\right)$ were dissociated from isolated chicken ventral spinal cord at E5.5, E6.5, and E7.5. The cells were incubated in the presence of $1 \mathrm{~nm}$ labeled BDNF or NT3. After EDAC cross-linking half of each sample was resuspended in SDS sample buffer and subjected to electrophoresis on a $6 \%$ polyacrylamide/SDS gel $(A)$. The other half of each sample was immunoprecipitated with anti-443 antibodies and then electrophoresed $(B)$. Cross-linking of labeled BDNF to NIH3T3 cells expressing full-length TrkB receptors was used as a positive control. $A$ was exposed overnight. The other samples were exposed for $12 \mathrm{~d}$. Positions of molecular size markers are indicated in kilodaltons.

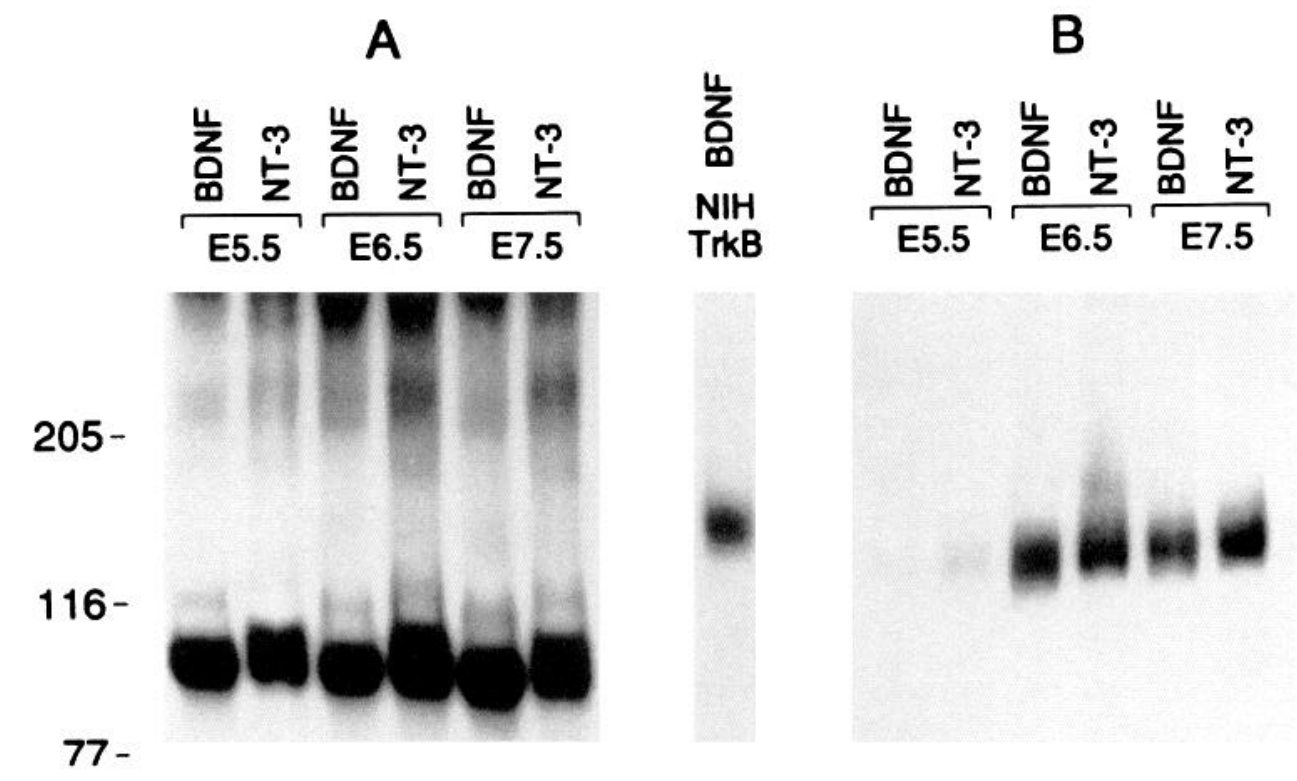

sion increases significantly by E20. This overall pattern is analogous to that seen in brain tissue. NT $-4 / 5$ cross-linked receptor complexes, as we have shown above, require longer exposure times and the receptor species identified are similar to the ones identified with BDNF (not shown). To characterize the specificities of the Trk receptors expressed in E15 rat ventral spinal cord we performed receptor cross-linking in the presence of

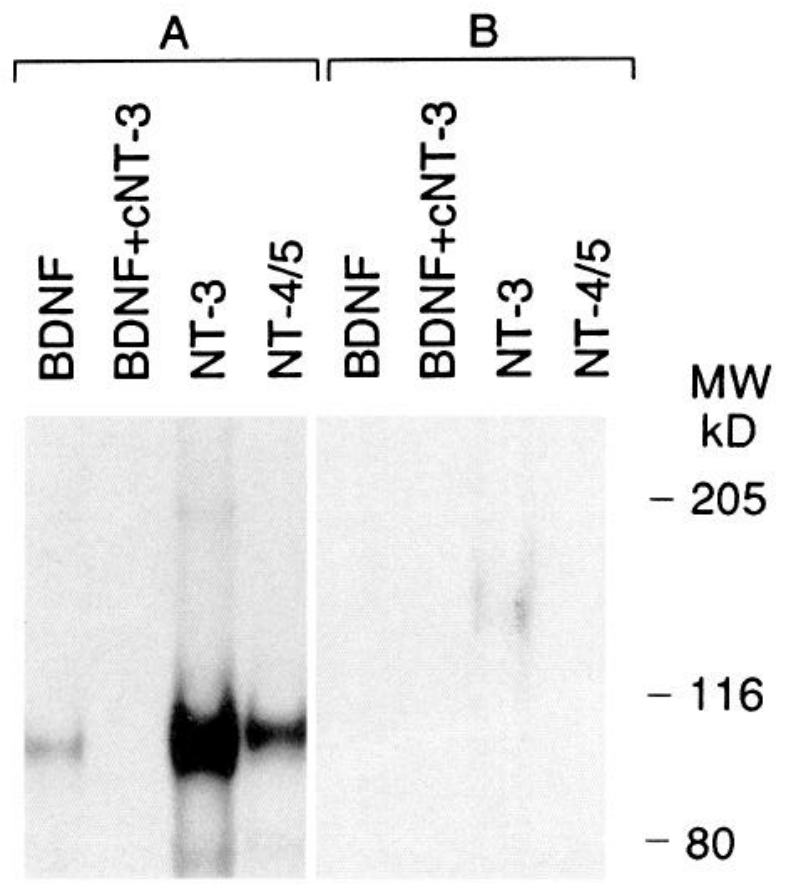

Figure 11. Binding of neurotrophins to purified avian motoneurons. Chicken E5 motoneurons were purified as described in Materials and Methods. Equal amounts of cells $\left(\sim 1 \times 10^{5} /\right.$ assay $)$ were incubated in the presence of the indicated labeled neurotrophins with or without a 20 -fold excess of unlabeled NT-3. After EDAC cross-linking the samples were resuspended in sample buffer and subjected to electrophoresis on a $6 \%$ polyacrylamide/SDS gel $(A)$, or immunoprecipitated with anti$443 / 444$ antibodies and treated as above $(B)$. The fixed and dried gels were exposed for $3 \mathrm{~d}(A)$ or $12 \mathrm{~d}(B)$. Positions of molecular size markers are indicated in kilodaltons. heterologous unlabeled ligands (Fig. 13). Our results demonstrate the presence of highly specific functional receptor complexes for BDNF and NT-3. Interestingly, NT-4/5 was crosslinked only to full-length TrkB, as shown by full displacement with excess $(20 \times)$ unlabeled BDNF.

We then analyzed the specificity of neurotrophin cross-linking to purified motoneurons obtained from E15 rat embryos by the method described earlier (Camu and Henderson, 1992) in the presence or absence of heterologous ligands (Fig. 13). The results, in agreement with our observations in ventral spinal cord tissue, demonstrate the presence of considerable levels of fulllength TrkB and TrkC receptors. A lower level of truncated TrkB was also present in E15 motoneurons although the fulllength isoform was the most abundant one. With E15 rat motoneurons under the cross-linking conditions used for BDNF and NT-3 we found very low to undetectable levels of NT-4/5 binding to a $t r k$ family receptor identified by the anti-443/444 antibodies, which most probably was due to the lower efficiency of EDAC to link NT-4/5 covalently to the TrkB receptor.

\section{Neurotrophin receptors in the retinotectal system}

Retinal ganglionic neurons have been reported to be responsive to BDNF (Johnson et al., 1986), and therefore we analyzed retinal tissue and the optic tectum, which contains the terminals of these neurons projecting to the brain. In E15 chicken neural retina only full-length TrkB could be detected, whereas in the optic tectum very high levels of both truncated and full-length TrkB were found (Fig. 14). In the case of NT-4/5, again we found no detectable binding/cross-linking to chicken tissues, neuronal or non-neuronal, when immunoprecipitation with anti$443 / 444$ antibodies was used. In this study only chicken tissues were analyzed at one developmental age. A detailed analysis of neurotrophin receptors in developing tissues (embryonic and postnatal) of the mammalian visual system using the same crosslinking methodology applied here has recently been described (Allendoerfer et al., 1993).

\section{Peripheral nerves}

DRG-derived neurons from E9 chick embryos have previously been shown to respond to BDNF and NT-3. However, sym- 


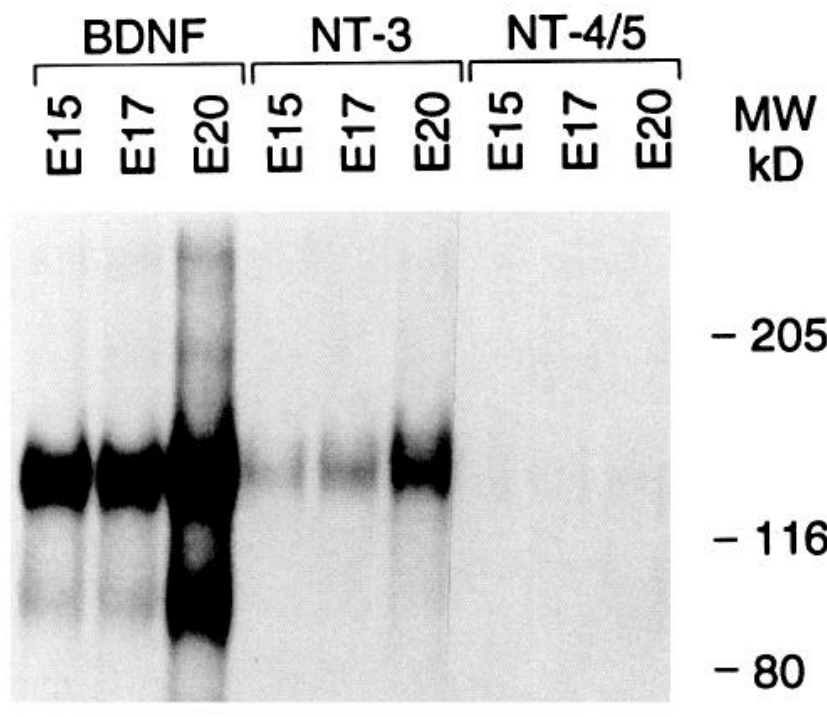

Figure 12. Developmental profile of affinity-labeled BDNF, NT-3, and NT-4/5 receptors in rat ventral spinal cord. Dissociated cells $\left(1 \times 10^{6} /\right.$ assay) were incubated in the presence of $1 \mathrm{~nm}$ of the indicated labeled neurotrophins. Following EDAC cross-linking and immunoprecipitation with a mixture of anti-443/444 antibodies, the samples were treated as described in Figure 9. The fixed and dried gel was exposed for $10 \mathrm{~d}$. Positions of molecular size markers are indicated in kilodaltons.

pathetic neurons are not responsive to BDNF. Therefore, we analyzed neurotrophin receptors in DRG, and compared them with sympathetic ganglia at two different embryonic times. The E9 time point precedes and E14 follows the phase of naturally occurring cell death of these neural crest-derived neurons. DRG at E9 displayed functional receptors for BDNF and NT-3 that corresponded to the full-length forms of TrkB and TrkC (Fig. 15). The signal obtained with NT-3 was particularly intense compared to BDNF. By E14 in DRG neurons there was a clear decrease in neurotrophin receptor expression that appears to coincide with the onset of dependence on neurotrophins of DRG neurons. On the other hand, purified sympathetic neurons showed abundant truncated TrkB on E9 that decreased to undetectable levels by E14. Specific NT-3 cross-linking indicative of fulllength TrkC was detectable on both E9 and E14. These findings support that E14 sympathetic neurons survive when treated with NT-3, but not with BDNF.

\section{Neurotrophin receptors in non-neuronal tissues}

Surprisingly, in addition to neuronal tissues we also detected functional neurotrophin receptors in some embryonic avian nonneuronal tissues: liver, skeletal muscle, gut, and kidney (Fig. 14). The pattern of TrkB and TrkC expression in these tissues appears to differ significantly from those found in neuronal tissues. High levels of a product that most likely represents truncated TrkC were found in several embryonic chicken tissues, while truncated TrkB was undetectable under identical experimental conditions (Fig. 14, top). We also found full-length TrkC receptors in dissected skeletal muscle and to a lesser degree in gut and kidney, whereas full-length TrkB was undetectable.

Several mouse non-neuronal embryonic tissues were also analyzed by neurotrophin cross-linking (Fig. 16). Similar to developing avian tissues, full-length TrkB was not detectable in isolated E13.5 tissues (limbs, heart, gut, and liver); however, receptors were present in whole-body samples. Only the trun-
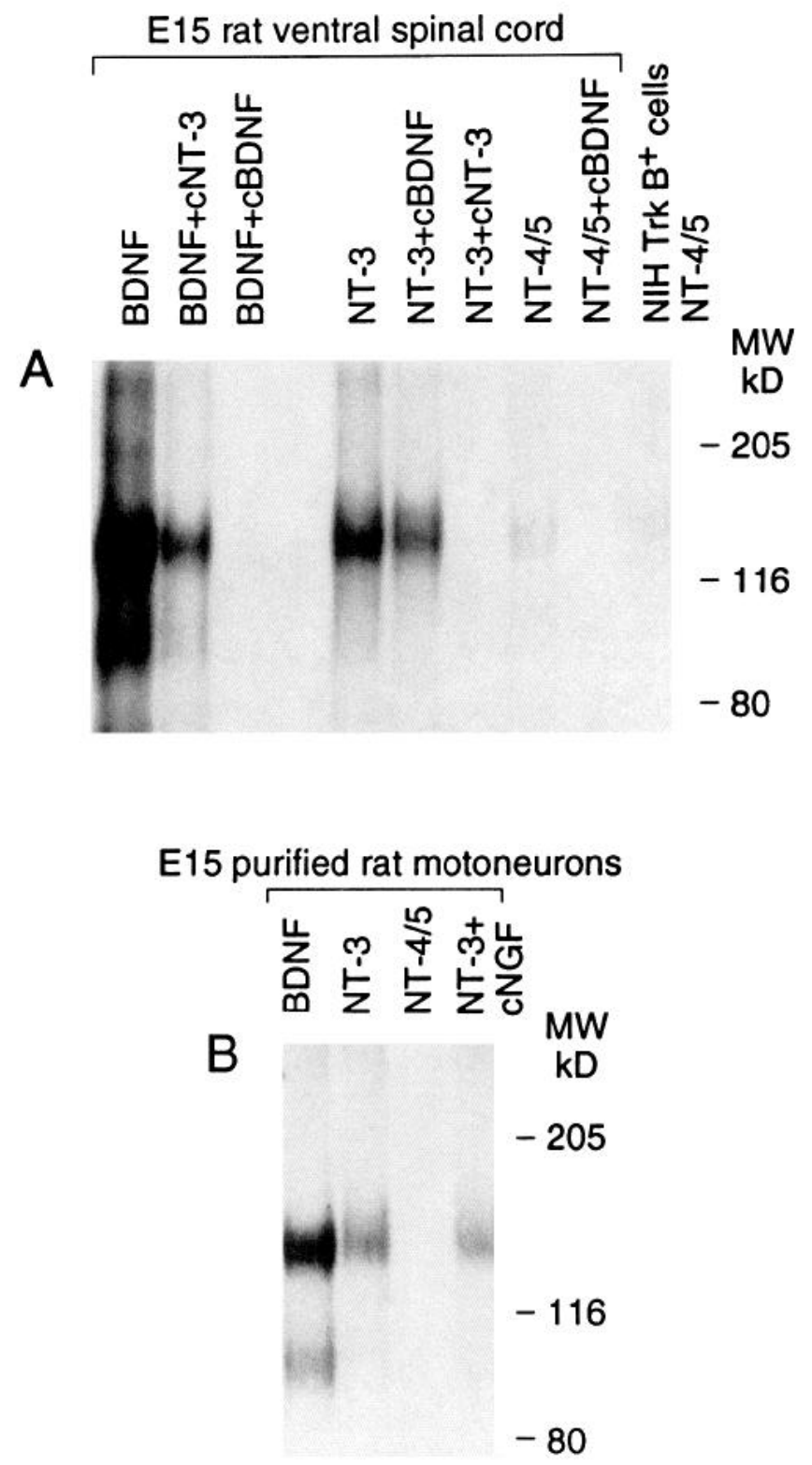

Figure 13. Specificity of neurotrophin binding to E15 rat ventral spinal cord and purified motoneurons. Dissociated cells $\left(\sim 5 \times 10^{5}\right.$ and $1 \times$ $10^{5} /$ assay, $A$ and $B$, respectively) were incubated in the presence of 1 $\mathrm{nM}$ labeled neurotrophins with or without an excess of unlabeled BDNF, NT-3 (150-fold), or NGF (1000-fold). After EDAC cross-linking the samples were immunoprecipitated with a mixture of anti-443/444 antibodies and treated as described under Materials and Methods. The fixed and dried gels were exposed for $14 \mathrm{~d}$. Positions of molecular size markers are indicated in kilodaltons.

cated form of TrkB could be detected in E12 whole body. Interestingly, by E13.5 there was a significant increase in truncated TrkB expression and full-length TrkB was first detected. In whole body, the BDNF cross-linked receptors may represent in part binding to neuronal tissues like spinal cord, sympathetic ganglia, and DRG because non-neuronal tissues isolated at the same embryonic time (E13.5) expressed very low amounts of TrkB binding. We also detected binding of BDNF to truncated TrkB in the placenta. Adult brain was used as a positive control.

In the mouse, expression of full-length TrkC was already detectable by E12 whole body and was considerably increased by E13.5. However, in contrast to avian non-neuronal embryonic 

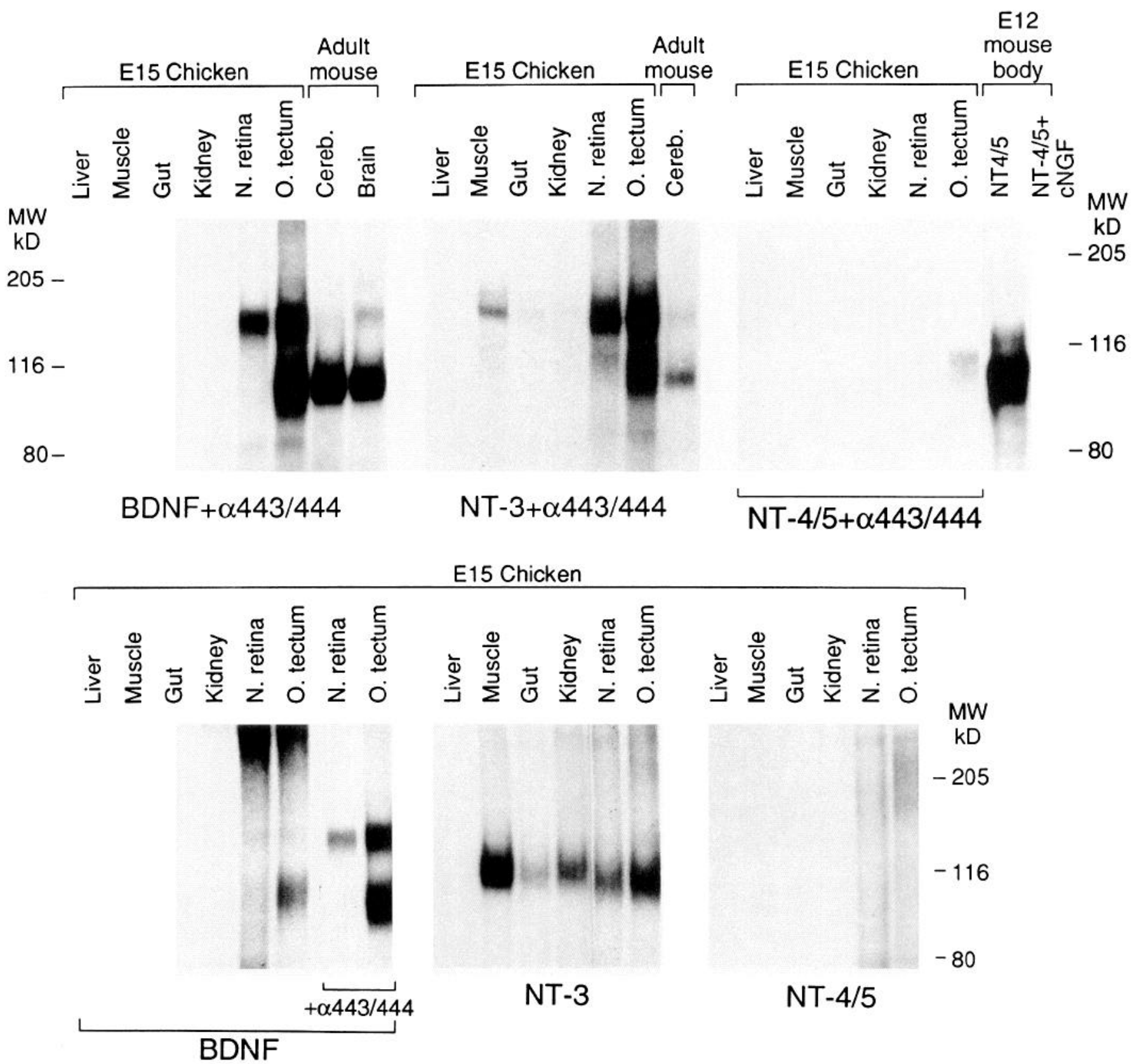

Figure 14. Identification of neurotrophin receptors in chicken non-neuronal tissues and in the developing visual system. Crude membranes were prepared from several E15 chicken tissues. The samples ( $3 \mathrm{mg}$ of total protein/assay) were incubated in the presence of $1 \mathrm{nM}$ labeled BDNF, NT3 , or NT-4/5. After EDAC cross-linking the tissues were either resuspended in lysis buffer and analyzed with $6 \%$ SDS-PAGE, or immunoprecipitated with a mixture of anti-443/444 antibodies and treated as described in Materials and Methods. All the incubation reactions, with the exception of NT-4/5 cross-linking to E12 mouse body, were done in the presence of a 1000-fold excess unlabeled NGF. In addition to E12 mouse body, adult mouse brain and cerebellum were used as positive controls. The fixed and dried gels were exposed for $5 \mathrm{~d}$.

tissues, we did not identify specific binding of NT-3 in isolated non-neuronal tissues (limbs, heart, gut, and liver) at these developmental stages in the mouse. Cross-linking of labeled NT4/5 followed, again with lower intensity, the BDNF binding profile when the reaction was immunoprecipitated with anti443/444 antibodies (Fig. 16). Control samples not immunoprecipitated clearly showed intense binding of NT-4/5 to p $75^{\text {NGFR }}$, the low-affinity NGF/neurotrophin receptor. The addition of cold NGF completely displaced the binding of NT-4/5 under these conditions. Interestingly, placental tissue expressed detectable levels of p75 $\mathrm{NGFR}$.

\section{Discussion}

We have analyzed various tissues from different embryonic and postnatal ages associated with neurogenesis, migration, differentiation, development of connections, cell death, remodeling, and aging. Neurotrophins, which act as survival factors, have also been reported to stimulate processes of cell proliferation, differentiation, as well as axonal and dendritic arborization (Cattaneo and McKay, 1990; Sieber-Blum, 1991; Kalcheim et al., 1992; Wright et al., 1992). A complete understanding of the complex and multiple functions neurotrophins play temporally 
and spatially in the various processes from neurogenesis to longterm survival of terminally differentiated neurons will require studies of neurotrophin and neurotrophin receptor gene expression, as well as studies of functional proteins encoded by these genes. Initial studies of neurotrophin gene expression have shown complex patterns during embryonic development (Ernfors et al., 1990; Hofer et al., 1990; Phillips et al., 1990; Rosenthal et al., 1990; Maisonpierre et al., 1991; Timmusk et al., 1993). Unfortunately, with the exception of NGF, the lack of specific and sensitive antibodies has not permitted a detailed analysis of tissue distribution of neurotrophin proteins. Reports of neurotrophin receptor (trk family members and p75) gene expression have underlined and extended our view of the complexity of potential roles neurotrophins play in development. Trk, $t r k \mathrm{~B}$, and $t r k \mathrm{C}$ genes were found (by Northern methods or by in situ hybridization) to be actively transcribed during development (Klein et al., 1990b; Lamballe et al., 1991; Middlemas et al., 1991; Merlio et al., 1992; Persson and Ibañez, 1993; Tessarollo et al., 1993; Tsoulfas et al., 1993). A direct analysis of functional neurotrophin receptors either by analysis of binding or by immunohistochemical identification of receptor proteins during embryonic development has not been reported. In the present study we addressed this question by a specific and sensitive methodology developed for this purpose.

The results described here demonstrate that BDNF, NT-3, and NT $-4 / 5$ receptors corresponding to full-length and truncated forms of TrkB and TrkC proteins are present in neuronal and non-neuronal tissues during embryonic and postnatal development. BDNF and NT-4/5 bind to full-length and truncated forms of TrkB, whereas NT-3 binds to full-length and truncated forms of TrkC, and to a lesser degree to the two forms of TrkB. Earlier reports established that BDNF, NT-3, and NT-4/5 were ligands of TrkB and TrkC (Klein et al., 1991b; Lamballe et al., 1991; Soppet et al., 1991; Squinto et al., 1991; Berkemeier et al., 1991; Yp et al., 1992; Tsoulfas et al., 1993). BDNF and NT$4 / 5$ bind to TrkB equally well, as determined in this study; however, NT-3's interaction with TrkB differs from the two other factors in affinity, kinetics, and probably structural details. Cross-linking of NT-4/5 to TrkB was not as efficient as BDNF or NT-3, most likely due to a limited availability of reactive side chains in NT-4/5 as compared with the other two factors. Furthermore, NT-4/5 could not be cross-linked to chicken receptors whereas mammalian BDNF and NT-3 showed no differences between mammalian and avian receptor binding. This finding may suggest that NT-4/5 differs more substantially between mammalian and avian forms (the latter have not been identified yet), which may support the proposal that NT-4 and NT-4/5 are species variants of the same molecular entity (Yp et al., 1992), and therefore we used the designation NT-4/5 in this article.

Radioiodinated ligand cross-linking is a convenient method to obtain information on the presence and some biochemical characteristics of functional receptors. The method provides very useful complementary information to $t r k, t r k \mathrm{~B}$, and $t r k \mathrm{C}$ mRNA expression regarding the appearance and size of the molecular forms of neurotrophin receptor proteins (Escandón et al., 1993). By extending the cross-linking technique using immunoprecipitation with two different antibodies, we were able to improve substantially the sensitivity and specificity of analyzing tissues. Using this method, we have identified fulllength forms of TrkB and TrkC, as well as the dominant truncated form of TrkB, which lacks the intracellular kinase domain,

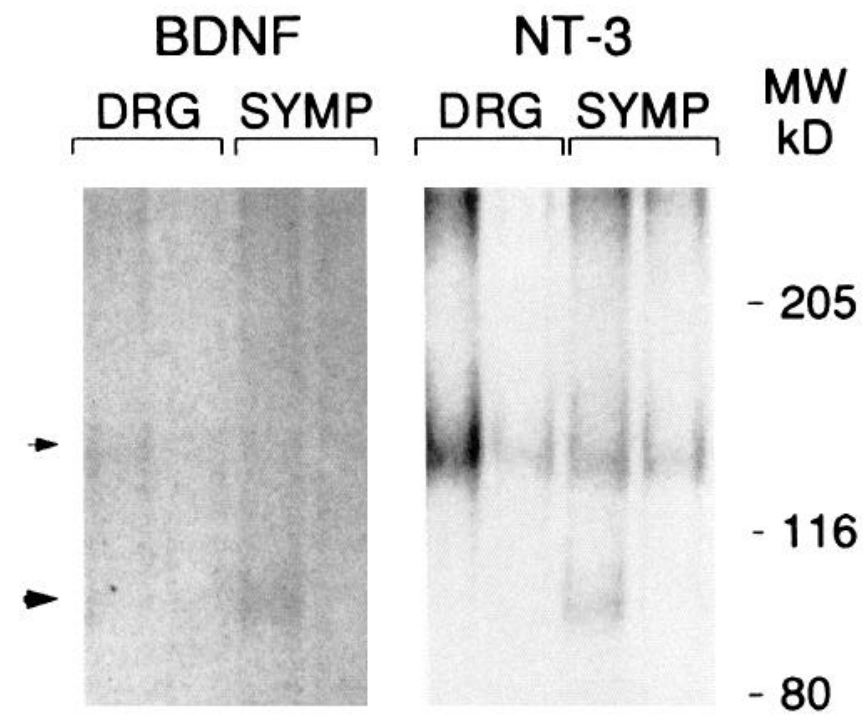

\section{A B A B A B A B}

Figure 15. Functional receptors for BDNF and NT-3 in sensory and sympathetic neurons. Cell suspensions ( $200 \mu \mathrm{g}$ of total protein/sample) were prepared from E9 $(A)$ or E14 $(B)$ isolated chicken dorsal root or sympathetic ganglia. The samples were incubated in the presence of 1 nM iodinated BDNF or NT-3. After EDAC cross-linking the samples were immunoprecipitated with a mixture of anti-443/444 antibodies. The tissues were resuspended in sample buffer and subjected to electrophoresis on a $6 \%$ SDS/polyacrylamide gel. The fixed and dried gels were exposed for $18 \mathrm{~d}$ (BDNF) or $10 \mathrm{~d}$ (NT-3). Positions of molecular size markers are indicated in kilodaltons.

in several developing tissues. By subtracting signals obtained with the two antibodies used, we also identified a receptor species that most likely represents truncated TrkC in some tissues.

One of the most important observations we have made is that during embryonic development of different tissues the first form of TrkB and TrkC expressed is their full-length form containing the tyrosine kinase domain. At the earliest time points investigated, very low or no truncated receptor forms (lacking a functional kinase domain) are present. In every case this is followed by a major upregulation of the expression of truncated receptor forms, whereas the full-length receptor remains either unchanged or only slightly decreased. This appears to be a quite general phenomenon that we observed in most tissues. Although we do not have a clear explanation for this developmental shift, several possibilities exist that have already been raised in reports describing truncated $t r k$ forms (Middlemas et al., 1991; Schneider and Schweiger, 1991). One possibility is that truncated trk receptor forms may downregulate the activity of the full-length forms by forming inactive dimers. It will be important to complement our findings with receptor phosphorylation data to test this hypothesis. Another possibility is that the truncated forms act as adhesion molecules and they function to maintain connections established with cells producing full-length receptor molecules. Furthermore, truncated Trks may act as localizing molecules to provide trophic support for specific neurons in a spatially defined manner (Jessell and Melton, 1992). Most major changes in receptor levels and the shift from full-length to truncated forms observed in our analysis take place during embryonic and early postnatal development, but subsequently tissuespecific patterns are established that appear to be maintained throughout adulthood. 


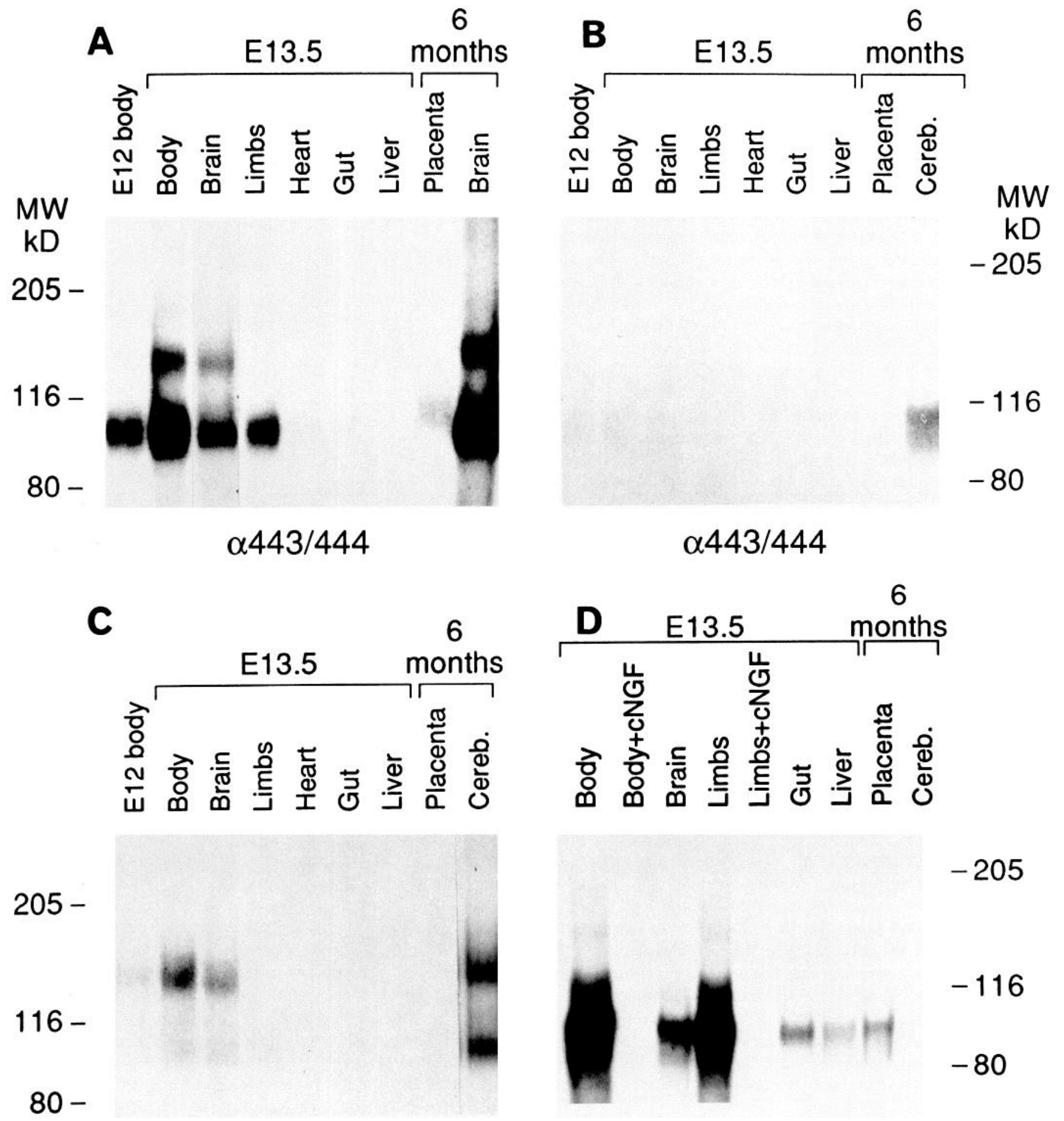

\section{$\alpha 443 / 444$}

Figure 16. Neurotrophin receptors in non-neuronal mouse tissues. Cell suspensions (1.5 $\mathrm{mg}$ of total protein/sample) prepared from various mouse tissues were incubated in the presence of $1 \mathrm{~nm}$ iodinated BDNF $(A)$, NT-3 $(B)$, or NT-4/5 $(C$ and $D)$. After EDAC cross-linking the samples were resuspended in lysis buffer and examined by electrophoresis on a $6 \% \mathrm{SDS} /$ polyacrylamide gel $(D)$, or followed by immunoprecipitation with a mixture of anti-443/444 antibodies $(A-C)$ and treated as above. Samples in $D$ were incubated with $(+c N G F)$ or without a 1000 -fold excess of unlabeled NGF.

NGF has been shown to act as a trophic agent for magnocellular cholinergic neurons of the basal forebrain (Hefti et al., 1989). It has recently been shown that BDNF like NGF but not NT-3 can rescue cholinergic neurons in the basal forebrain of rodents (Alderson et al., 1990; Knüsel et al., 1991, 1992). In addition, both BDNF and NT-3 have been reported to have effects on hippocampal neurons: both neurotrophins upregulate c-fos, but only NT-3 stimulates calbindin levels (Collazo et al., 
1992). In postnatal and aging brains we did not detect significant shifts of cross-linked receptor forms between the basal forebrain and the hippocampus. BDNF and more recently NT-4/5 have been shown to act as trophic factors in vitro for dopaminergic neurons of the substantia nigra (Hyman et al., 1991; Knüsel et al., 1991; Hynes and Rosenthal, 1993). However, the concentrations of both factors required to elicit the effect are at least 2 orders of magnitude greater than those required for other neurons. Furthermore, BDNF was found to be ineffective in vio on dopaminergic neurons in a lesion model (Knüsel et al., 1992). Using our method of affinity cross-linking, we were able to detect receptors for all three neurotrophins in neonatal substantia nigra and corpus striatum. The relative tissue levels of these receptors were approximately the same as in the basal lorebrain or in spinal cord, which are tissues responsive to neurotrophins (Knüsel et al., 1991, 1992; Henderson et al., 1993). This suggests that the low degree of neurotrophin responsiveness and the lack of in vivo response are not due to a lack of functional receptors.

In the ventral spinal cord obtained from chick embryos both BDNF and NT-3 showed no or barely detectable signals at E5.5, but there was intense labeling of full-length receptor forms by E6.5, suggesting that within this embryonic day motoneurons become neurotrophin responsive. In motoneurons purified from E5.5 embryos, again a very weak signal was found with BDNF and NT-3. This finding is in agreement with the lack of survival cffects of neurotrophins on chick motoncurons from E5-E5.5 embryos (Arakawa et al., 1990; Bloch-Gallego et al., 1991). In contrast, in E14-E20 rat ventral spinal cord intense labeling with BDNF, NT-3, and NT-4/5 was found. In motoneurons purified from $\mathrm{E} 15$ rat spinal cord, all three neurotrophins bound to TrkB and TrkC receptors. This is also in good agreement with cell culture studies showing that all three neurotrophins act as potent survival factors for these neurons (Henderson et al., 1993). The timing of motoneuron cultures from chick embryonic spinal cord thus may be critical for the analysis of neurotrophin cffects in this system.

Tsoulfas et al. (1993), using a sensitive RNase protection assay, have recently shown the presence of full-length and truncated forms of the $t r k \mathrm{C}$ gene in newborn mousc skeletal muscle, intestine, and kidney. However, using our affinity labeling procedure we were unable to detect functional receptors for NT-3 in those tissues. This may reflect differences in the sensitivity of these assays, or indicate a discrepancy in the relative levels of trkC-specific transcripts and the amount of functional NT-3 receptor proteins. We were surprised to find significant levels of full-length TrkC in E13.5 chicken skelctal muscle and somewhat lower levels in embryonic kidney and gut. We also identified large amounts of NT-3 cross-linking to what most probably represents truncated $\mathrm{TrkC}$ in embryonic avian skeletal muscle, gut, and kidney, but not liver. In comparison, iodinated BDNF failed to affinity label any trk receptors in the same avian embryonic tissues. On the other hand, we have detected binding of BDNF to truncated TrkB in embryonic mouse limbs and developing skin (data not shown). In situ hybridization studies of $t r k \mathrm{~B}$ expression in non-neuronal tissues have not been published to date. The presence of functional receptors identified by affinity labeling in non-neuronal tissues suggests the possibility of nonconventional developmental roles for the neurotrophins. An elaborate hypothesis for a role of neurotrophins in non-neuronal tissues has recently been described by Schecterson and Bothwell (1992). Our results warrant further investigation to identify novel physiological effects clicited by neu- rotrophins in those potentially responsive receptor-positive nonneuronal tissues.

\section{References}

Alderson RF, Alterman AL. Barde Y-A. Lindsay RM (1990) Brainderived neurotrophic factor increases survival and differentiated functions of rat septal cholinergic neurons in culture. Neuron 5:297-306.

Allendoerfer K, Cabelli R, Escandón E, Nikolics K, Shatz C (1993) Regulation of neurotrophin receptors during maturation of the mammalian visual system. J Neurosci, in press.

Arakawa $Y$, Sendtner M, Thoenen H (1990) Survival effect of ciliary neurotrophic factor (CNTF) on chick embryonic motoneurons in culture: comparison with other neurotrophic factors and cytokines. $J$ Neurosei 10:3507-3515

Berkemeier LR, Winslow JW. Kaplan DR, Nikolics K, Goeddel DV, Rosenthal A (1991) Neurotrophin-5, a novel neurotrophic factor that activates trk and trkB. Neuron 7:857 866 .

Bloch-Gallego E. Huchet M, El M'handi H, Xie FK. Tanaka H. Henderson CE (1991) Survival in vitro of motoneurons identified or purified by novel antibody-based methods is selectively enhanced by muscle-derived factors. Development 111:221-232.

Camu W, Henderson CE (1992) Purification of embryonic rat motoneurons by panning on a monoclonal antibody to the low-atfinity NGF receptor. J Neurosci Methods 44:59-70.

Cattaneo E, McKay R (1990) Proliferation and differentiation of neuronal stem cells regulated by nerve growth factor. Nature 347:762765.

Chao MV (1997) Neurotrophin receptors: a window into neuronal differentiation. Neuron 9:583-593.

Collazo D, Takahashi H. McKay RDG (1992) Cellular targets and trophic functions of neurotrophin-3 in the developing rat hippocampus. Neuron 9:643-656.

Davies AM, Horton A. Burton LE, Schmelzer C, Vandlen R, Rosenthal A (1993) Neurotrophin-4/5 is a mammalian-specific survival factor for distinct populations of sensory neurons. J Neurosci, in press.

Ernfors P, Wetmore C, Olson L, Persson H (1990) Identification of cells in rat brain and peripheral tissues expressing $\mathrm{mRNA}$ for members of the nerve growth factor family. Neuron 5:511-526.

Escandón E. Chao MV (1989) Developmental expression of the chicken nerve growth factor receptor gene during brain morphogenesis. Dev Brain Res 47:187-196.

Fscandón $\mathrm{E}$, Chan MV (1990) Identification of high-and low-affinity NGF receptors during development of the chicken central nervous system. Dev Biol 142:293-300.

Escandón E. Burton LE, Szonyi E, Nikolics K (1993) Characterization of neurotrophin receptors by affinity crosslinking. J Neurosci Res 34: $601-613$.

Hefti F, Hartikka J, Knüsel B (1989) Function of neurotrophic factors in the adult and aging brain and their possible use in the treatment of neurodegenerative diseases. Neurobiol Aging 10:515-534.

Hempstead BL, Martin-Lanca D, Kaplan DR, Parada LF, Chao MV (1991) High-affinity NGF binding requires coexpression of the $t r k$ proto-oncogene and the low-affinity NGF receptor. Nature 350:678683.

Henderson CE, Camu W, Mettling C, Gouin A, Poulsen K, Karihaloo M, Rullamas J, Fvans T. McMahon SB, Armanini MP, Berkemeier L, Phillips HS, Rosenthal A (1993) Neurotrophins promote motor neuron survival and are present in embryonic limb bud. Nature 363: 266270

Hofer M, Pagliusi SR, Hohn A, Leibrock J, Barde Y-A (1990) Regional distribution of brain-derived neurotrophic factor mRNA in the adult mouse brain. EMBO J 9:2459-2464.

Holtzman DM, Li Y, Parada LF, Kinsman S, Chen CK, Valletta JS, Zhou J, Long JB, Mobley WC (1992) pl40 mRNA marks NGFresponsive forebrain neurons: evidence that trk gene expression is induced by NGF. Neuron 9:465-478.

Hyman C, Hofer M, Barde Y-A, Juhasz M, Yancopoulos GD, Squinto SP, Lindsay RM (1991) BDNF is a neurotrophic factor for dopaminergic neurons of the substantia nigra. Nature 350:230-232.

Hynes M. Rosenthal A (1993) Neurotrophin-4/5 promotes survival of dopaminergic neurons, and is present in embryonic striatum. J Neurosci Res, in press.

Jessell TM, Melton DA (1992) Diffusible factors in vertebrate embryonic induction. Cell 68:257-270. 
Johnson D, Lanahan A, Buck CR, Sehgal A, Morgan C. Mercer E, Bothwell M, Chao MV (1986) Expression and structure of the human NGF receptor. Cell 47:545-554.

Kalcheim C, Carmeli C, Rosenthal A (1992) Neurotrophin-3 is a mitogen for neural crest cells. Proc Natl Acad Sci USA 89:1661-1665.

Kaplan DR, Martin-Zanca D, Parada LF (1991a) Tyrosine phosphorylation and tyrosine kinase activity of the trk proto-oncogene product induced by NGF. Nature 350:158-160.

Kaplan DR, Hempstead BL, Martin-Zanca D, Chao MV, Parada LF (1991b) The $t r k$ proto-oncogene product: a signal transducing receptor for nerve growth factor. Science 252:554-558.

Klein R, Conway D, Parada LF, Barbacid M (1990a) The TrkB tyrosine protein kinase gene codes for a second ncurogenic receptor that lacks the catalytic kinase domain. Cell 61:647-656.

Klein R, Martin-Zanca D, Barbacid M, Parada LF (1990b) Expression of the tyrosine kinase receptor gene TrkB is confined to the murine embryonic and adult nervous system. Development 4:845-850.

Klein R, Jing SQ, Nanduri V, O'Rourke E, Barbacid M (1991a) The trk proto-oncogene encodes a receptor for nerve growth factor. Cell 65:189-197.

Klein R, Nanduri V, Jing SA, Lamballe F, Tapley P, Bryant S, CordonCardo C, Jones KR, Reichardt LF. Barbacid M (1991b) The trkB tyrosine protein kinase is a receptor for brain-derived neurotrophic factor and neurotrophin-3. Cell 66:395-403.

Knüsel B. Winslow JW, Rosenthal A, Burton LE, Seid DP, Nikolics K, Hefti $F$ (1991) Promotion of central cholinergic and dopaminergic neuron differentiation by brain-derived neurotrophic factor but not neurotrophin-3. Proc Natl Acad Sci USA 88:961-965.

Knüsel B, Beck KD, Winslow JW, Rosenthal A, Burton LE, Widmer HR, Nikolics K, Hefti F (1992) Brain-derived neurotrophic factor administration protects basal forebrain cholinergic but not nigral dopaminergic neurons from degenerative changes after axotomy in the adult rat brain. J Neurosci 12:4391-4402.

Lamballe F, Klein R, Barbacid M (1991) TrkC, a new member of the trk family of tyrosine kinases, is a receptor for neurotrophin-3. Cell $66: 967-979$

Maisonpierre PC, Belluscio L, Friedman B, Alderson RF, Wiegand SJ, Furth ME, Lindsay RM, Yancopoulos GD (1991) NT-3, BDNF, and NGF in the developing rat nervous system: parallel as well as reciprocal patterns of expression. Neuron 5:50l-509.

Martin-Zanca D, Barbacid M, Parada LF (1990) Expression of the trk proto-oncogene is restricted to the sensory cranial and spinal ganglia of neural erest origin in mouse development. Genes Dev 4:683-694

Merlio JP, Ernfors P, Jaber M, Persson H (1992) Molecular cloning of rat TrkC and distribution of cells expressing messenger RNAs for members of the $t r k$ family in the rat central nervous system. Neuroscience 51:513-532.

Middlcmas DS, Lindberg RA, Hunter T (1991) TrkB, a neural receptor protein-tyrosine kinase: evidence for a full-length and two truncated receptors. Mol Cell Biol 11:143-153.

Oppenheim RW, Yin QW, Prevette D, Yan Q (1992) Brain-derived neurotrophic factor rescucs developing avian motoneurons from cell death. Nature 360:755-757.

Persson H, Ibañez CF (1993) Role and expression of neurotrophins and the trk family of tyrosine kinase receptors in neural growth and rescue after injury. Curr Opin Neurol Neurosurg 6:11-18.

Phillips HS, Hains JM, Laramee GR, Rosenthal A Winslow IW (1990) Widespread expression of BDNF but not NT-3 by target arcas of basal forebrain cholinergic neurons. Science 250:290-294.

Radeke MJ, Misko TP, Hsu C, Herzenberg LA, Shooter E (1987) Gene transfer and molecular cloning of the rat nerve growth factor receptor. Nature 325:593-597.

Rodriguez-Tébar A, Dechant G, Barde Y-A (1990) Binding of brainderived neurotrophic factor to the nerve growth factor receptor. Neuron $4: 487-492$.
Rodriguez-Tébar A, Dechant G, Gotz R, Barde Y-A (1992) Binding of neurotrophin-3 to its neuronal receptors and interactions with nerve growth factor and brain-derived neurotrophic factor. EMBO J 11: 917-922.

Rosenthal A, Goeddel DV, Nguyen T, Lewis M, Shih A, Laramee GR, Nikolics K, Winslow JW (1990) Primary structure and biological activity of a novel human neurotrophic factor. Neuron 4:767-773.

Rosenthal A, Goeddel DV, Nguyen T, Martin E, Burton LE, Shih A, Laramee GR, Wurm F, Mason A, Nikolics K, Winslow JW (1991) Primary structure and biological activity of human brain-derived neurotrophic factor. Endocrinology 129:1289-1294.

Schecterson LC, Bothwell M (1992) Novel roles for neurotrophins are suggested by BDNF and NT-3 mRNA expression in developing neurons. Ncuron 9:449-463.

Schmelzer CH, Burton LE, Chan W-P, Martin E, Gorman C, CanovaDavis E, Ling VT, Sliwkowski MB, McCray G, Briggs JA, Nguyen TH, Polastri $G$ (1992) Biochemical characterization of recombinant human nerve growth factor. J Neurochem 59:1675-1683.

Schneider R, Schweiger M (1991) A novel modular mosaic of cell adhesion motifs in the extracellular domains of the neurogenic trk and TrkB tyrosine kinase receptors. Oncogene 6:1807-1811.

Sendtner M, Holtmann B. Kolbeck R, Thoenen H, Barde Y-A (1992) Brain-derived neurotrophic factor prevents the death of motoneurons in newborn rats after ncrve section. Nature 360:757-759.

Sicber-Blum M (1991) Role of the neurotrophic factors BDNF and NGF in the commitment of pluripotent neural crest cells. Neuron 6:949-955.

Soppet D, Escandón E, Maragos J, Middlemas DS, Reid SW, Blair J, Burton LE, Stanton B, Kaplan DR, Hunter T, Nikolics K, Parada LF (1991) The neurotrophic factors brain-derived neurotrophic factor and neurotrophin-3 are ligands for the TrkB tyrosine kinase receptor. Cell 65:895-903

Squinto SP, Stitt TN, Aldrich TH, Davis S, Bianco SM, Radziejewsk C, Glass DJ, Masiakowski P, Furth ME, Valenzuela DM, Yancopoulos GD (1991) TrkB encodes a functional receptor for brainderived neurotrophic factor and neurotrophin-3 but not nerve growth factor. Cell 65:885-893

Tessarollo L, Tsoulfas P, Martin-Zanca D, Gilbert DJ, Jenkins NA, Copeland NG, Parada LF (1993) TrkC, a receptor for neurotrophin3 , is widely expressed in the devcloping nervous system and in nonneuronal tissues. Development 1 18:463-475.

Timmusk T, Belluardo N, Nagel H, Persson H (1993) Widespread and developmentally regulated expression of neurotrophin- 4 mRNA in rat brain and peripheral tissues. Eur J Neurosci 5:605-613

Tsoulfas P, Soppet D, Escandón E, Tessarollo L, Mendoza-Ramirez J-L. Rosenthal A, Nikolics K, Parada LF (1993) The rat TrkC locus encodes multiple neurogenic receptors that exhibit differential response to NT-3 in PC12 cells. Neuron 10:975-990.

Vale RD, Shooter EM (1985) Assaying binding of nerve growth factor to cell surface receptors. Methods Enzymol 109:21-39

Wright EM, Vogel KS, Davies AM (1992) Neurotrophic factors promote the maturation of developing sensory neurons before they become dependent on these factors for survival. Neuron 9:139-150.

Yan Q, Johnson EM Jr (1987) A quantitative study of the developmental expression of nerve growth factor (NGF) receptor in rats. Dev Biol 121:139-148.

Yan Q, Elliott J, Snider WD (1992) Brain-derived neurotrophic factor rescues spinal motor neurons from axotomy-induced cell death. Nature 360:753-755.

Yp NY, Ibanez CF, Nye SH, McClain J, Jones PF, Gies DR, Belluscio L, Le Beau MM, Espinoza R III, Squinto SP, Persson H, Yancopoulos GD (1992) Mammalian neurotrophin-4: structure, chromosomal localization, tissue distribution, and receptor specificity. Proc Natl Acad Sci USA 89:3060-3064. 